\title{
Contribution of Astroglial Cx43 Hemichannels to the Modulation of Glutamatergic Currents by D-Serine in the Mouse Prefrontal Cortex
}

\author{
Claire Meunier, ${ }^{1,2,3}$ Nan Wang, ${ }^{4}$ Chenju Yi, ${ }^{1,2,3}$ Glenn Dallerac, ${ }^{1,2,3}$ Pascal Ezan, ${ }^{1,2,3}$ Annette Koulakoff, ${ }^{1,2,3}$ \\ 는 Leybaert, ${ }^{4}$ and ${ }^{\circ}$ Christian Giaume ${ }^{1,2,3}$ \\ ${ }^{1}$ Collège de France, Center for Interdisciplinary Research in Biology/Centre National de la Recherche Scientifique, Unité Mixte de Recherche 7241/Institut \\ National de la Santé et de la Recherche Médicale U1050, 75231 Paris Cedex 05, France, ${ }^{2}$ University Pierre et Marie Curie, 75005 Paris, France, ${ }^{3}$ MEMOLIFE \\ Laboratory of Excellence and Paris Science Lettre Research University, 75005 Paris, France, and ${ }^{4}$ Physiology Group, Department of Basic Medical Sciences, \\ Faculty of Medicine and Health Sciences, Ghent University, 9000 Ghent, Belgium
}

Astrocytes interact dynamically with neurons by modifying synaptic activity and plasticity. This interplay occurs through a process named gliotransmission, meaning that neuroactive molecules are released by astrocytes. Acting as a gliotransmitter, D-serine, a coagonist of the NMDA receptor at the glycine-binding site, can be released by astrocytes in a calcium $\left[\mathrm{Ca}^{2+}\right]_{\mathrm{i}}$-dependent manner. A typical feature of astrocytes is their high expression level of connexin43 (Cx43), a protein forming gap junction channels and hemichannels associated with dynamic neuroglial interactions. Pharmacological and genetic inhibition of $\mathrm{Cx} 43$ hemichannel activity reduced the amplitude of NMDA EPSCs in mouse layer 5 prefrontal cortex pyramidal neurons without affecting AMPA EPSC currents. This reduction of NMDA EPSCs was rescued by addition of D-serine in the extracellular medium. LTP of NMDA and AMPA EPSCs after high-frequency stimulation was reduced by prior inhibition of $\mathrm{Cx} 43$ hemichannel activity. Inactivation of D-serine synthesis within the astroglial network resulted in the reduction of NMDA EPSCs, which was rescued by adding extracellular D-serine. We showed that the activity of Cx43 hemichannels recorded in cultured astrocytes was $\left[\mathrm{Ca}^{2+}\right]_{\mathrm{I}}$ dependent. Accordingly, in acute cortical slices, clamping $\left[\mathrm{Ca}{ }^{2+}\right]_{\mathrm{i}}$ at a low level in astroglial network resulted in an inhibition of NMDA EPSC potentiation that was rescued by adding extracellular D-serine. This work demonstrates that astroglial $\mathrm{Cx} 43$ hemichannel activity is associated with $\mathrm{D}$-serine release. This process, occurring by direct permeation of D-serine through hemichannels or indirectly by $\mathrm{Ca}^{2+}$ entry and activation of other $\left[\mathrm{Ca}^{2+}\right]_{\mathrm{i}}$-dependent mechanisms results in the modulation of synaptic activity and plasticity.

Key words: astrocyte; connexin; gliotransmitter; hemichannel; neuroglial interaction; prefrontal cortex

\section{Significance Statement}

We recorded neuronal glutamatergic (NMDA and AMPA) responses in prefrontal cortex (PFC) neurons and used pharmacological and genetic interventions to block connexin-mediated hemichannel activity specifically in a glial cell population. For the first time in astrocytes, we demonstrated that hemichannel activity depends on the intracellular calcium concentration and is associated with D-serine release. Blocking hemichannel activity reduced the LTP of these excitatory synaptic currents triggered by high-frequency stimulation. These observations may be particularly relevant in the PFC, where D-serine and its converting enzyme are highly expressed.

\section{Introduction}

An important step in establishing the occurrence of dynamic neuroglial interactions has been the demonstration that glial cells

\footnotetext{
Received July 11, 2016; revised May 16, 2017; accepted June 10, 2017.

Author contributions: C.M., L.L., and C.G. designed research; C.M., N.W., C.Y., and P.E. performed research; C.M., N.W., C.Y., and L.L. analyzed data; C.M., G.D., A.K., L.L., and C.G. wrote the paper.

This work was supported by the Agence Nationale pour la Recherche grant AstroGlo (Grant 06-NEURO-004-01 to C.G.), the the Fund for Scientific Research Flanders, Belgium (Grants G.0298.11N, G.0571.12N, G.0A54.13N, and G.0A82.13N to L.L. and N.W.), and the Interuniversity Attraction Poles Program P7/10. We thank Nicole Ropert for
}

can deliver neuroactive molecules called "gliotransmitters" that affect neurotransmission (Kettenmann and Zorec, 2013). These gliotransmitters include neurotransmitters (ATP, glutamate), ei-

helpful discussions and comments on the manuscript, Philippe Fossier for useful interactions, and K. Willecke and $\mathrm{M}$. Theis for providing the $\mathrm{C} \times 3 \mathrm{~K} 0 \mathrm{mice}$.

The authors declare no competing financial interests.

Correspondence should be addressed to Dr. Christian Giaume, CIRB Collège de France,11 place Marcelin Berthelot, 75231 Paris Cedex 05, France. E-mail: christian.giaume@college-de-france.fr.

DOI:10.1523/JNEUROSCI.2204-16.2017

Copyright $\odot 2017$ the authors $\quad 0270-6474 / 17 / 379064-12 \$ 15.00 / 0$ 
cosanoids, lactate, and the cytokine tumor necrosis factor alpha, which can be released from astrocytes through several pathways. $\mathrm{D}$-serine is another interesting gliotransmitter that is also released by astrocytes (Martineau et al., 2008) and acts as an agonist at the glycine site of NMDARs in neurons (Mothet et al., 2000; Martineau et al., 2006; Wolosker, 2007), playing important roles in glutamatergic transmission and synaptic plasticity (Mothet et al., 2005; Panatier et al., 2006; Fossat et al., 2012; Papouin et al., 2012). Interestingly, memory processes rely on the capacity to express functional plasticity, notably long-lasting changes in synaptic strength driven by NMDAR activation (Morris, 2013), and it has been shown that D-serine release from astrocytes, dependent on their intracellular calcium concentration $\left[\mathrm{Ca}^{2+}\right]_{\mathrm{i}}$, regulates LTP in hippocampus (Henneberger et al., 2010). Initially, in vitro and immunohistochemical studies suggested that serineracemase, the L- to D-serine-converting enzyme, was found only in astrocytes, which were therefore considered as the main source of D-serine in the brain (Schell et al., 1995; Wolosker et al., 1999). However, more recent studies indicate a neuronal expression of serine racemase (Miya et al., 2008; Ding et al., 2011; Ehmsen et al., 2013; Wolosker et al., 2016). Therefore, it is now accepted that both cell types produce and use D-serine as a key signaling molecule (Martineau et al., 2014).

It has been suggested that alterations in the extracellular D-serine level leads to neurological and psychiatric disorders (Martineau et al., 2014). In this context, the prefrontal cortex (PFC) is thought to be involved in the physiopathological development of schizophrenia because hypofunction of the PFC (Tan et al., 2007) and altered glutamatergic transmission have been observed in subjects with schizophrenia (Lewis et al., 2003; Poels et al., 2014). So far, deficits in glutamatergic transmission have been considered to be mostly of neuronal origin. However, recent studies suggest that astrocytes could also contribute to the control of glutamatergic synaptic transmission (Bernardinelli et al., 2014). D-serine has been showed to be released by astrocytes after $\left[\mathrm{Ca}^{2+}\right]_{\mathrm{i}}$-dependent vesicular fusion of either large (Kang et al., 2013) or small synaptic-like vesicles (Bezzi et al., 2004; Martineau et al., 2008, 2013), but it is not excluded that alternative nonvesicular pathways may be involved. One such mechanism consists of the opening of connexin $(\mathrm{Cx})$ hemichannels, which may also contribute to D-serine release either directly as a pathway for diffusion or indirectly by facilitating $\mathrm{Ca}^{2+}$ entry that subsequently activates other $\left[\mathrm{Ca}^{2+}\right]_{\mathrm{i}}$-dependent $\mathrm{D}$-serine release mechanisms. Indeed, in the brain, astrocytes express a large amount of these gap junction proteins (Giaume et al., 2013). Interestingly, Cx43 hemichannel activity has already been associated with the release of gliotransmitters such as glutamate and ATP (Ye et al., 2003; Kang et al., 2008; Stehberg et al., 2012), leading to the modulation of synaptic transmission in hippocampus (Chever et al., 2014; Abudara et al., 2015) and olfactory bulb (Roux et al., 2015).

In the present study, we investigated whether $\mathrm{Cx} 43$ hemichannel activity is associated with D-serine release by PFC astrocytes and thus affects neuroglial interaction and synaptic plasticity. For this purpose, we recorded NMDA and AMPA EPSCs in pyramidal neurons and used pharmacological and genetic interventions to suppress $\mathrm{Cx} 43$ hemichannel activity in astrocytes. We were able to show that the $\left[\mathrm{Ca}^{2+}\right]_{\mathrm{i}^{-}}$and serine racemase-dependent release of D-serine from astrocytes affected NMDA EPSCs. The latter were decreased by preventing $\mathrm{Cx} 43$ hemichannel activity in astrocytes and were rescued by addition of extracellular D-serine. Although the intimate release mechanism from astrocytes was not a focus of our investigation, we showed that inhibition of Cx43 hemichannel activity impacted synaptic plasticity because it reduced LTP of NMDA and AMPA EPSCs triggered by highfrequency stimulation (HFS).

\section{Materials and Methods}

\section{Experiments}

All experiments were performed according to the European Community Council Directives of January 1, 2013 (2010/63/EU) and followed the Institut National de la Santé et de la Recherche Médicale (INSERM) guidelines for the ethical treatment of animals. Experiments were also done in accordance with institutional French (Comité Opérationnel pour l'Ethique dans les Sciences de la Vie du Centre National de la Recherche Scientifique, CNRS) and international (National Institutes of Health) standards and legal regulations (Ministère de l'Agriculture et de la Pêche) for the use and care of animals. All efforts were made to minimize the number of animals used and their suffering.

\section{Animals}

Wild-type and transgenic hGFAP-eGFP mice with astrocytes expressing the enhanced green fluorescent protein (eGFP) under the control of a human glial fibrillary acidic protein (hGFAP) promoter (Nolte et al., 2001) were used as controls. To assess astroglial $C x$ functions, we used the $C x 43^{\mathrm{f} / \mathrm{fl}}$ : GFAP-cre (Cx43 KO) mouse line to selectively knock out $\mathrm{Cx} 43$ in astrocytes (Theis et al., 2003). Mice of either sex were used in this study.

\section{Cell cultures}

Astrocytes in culture were prepared from the cortex of newborn C57BL/6 mice as described previously (Même et al., 2006). Briefly, the cortices were dissected, their meninges were peeled off, and the tissue was mechanically dissociated in PBS supplemented with D-glucose (33 mм). Cells were seeded on poly-ornithine-coated 100 -mm-diameter plastic dishes at a density of $2 \times 10^{6}$ cells/dish in DMEM supplemented with penicillin $(10 \mathrm{U} / \mathrm{ml})$, streptomycin $(10 \mu \mathrm{g} / \mathrm{ml}$; Invitrogen $)$, and $10 \%$ FCS. When cells had reached confluence, $1 \mu \mathrm{M}$ cytosine-arabinoside was added to the culture medium for $3 \mathrm{~d}$ to prevent microglia proliferation. Medium was changed twice a week and secondary cultures were used after 1 week. Secondary astrocyte cultures were obtained by harvesting subconfluent 1-week-old primary cultures with trypsin-EDTA and plating on poly-ornithine-coated 14 -mm-diameter glass coverslips $(1.5 \times$ $10^{5}$ cells) in the same culture conditions.

\section{Measurement of hemichannel activity in cultured astrocytes}

Dye uptake in cultured astrocytes. Ethidium bromide (EtBr, $314 \mathrm{Da})$ uptake was measured in cultured astrocytes in control conditions and after treatment with the $\mathrm{Ca}^{2+}$ ionophore ionomycin $(1 \mu \mathrm{M})$. Cultured astrocytes were preincubated in standard HEPES buffer containing the following (in $\mathrm{mM}$ ): $\mathrm{NaCl} 150, \mathrm{KCl} 5.4, \mathrm{MgCl}_{2} 1, \mathrm{CaCl}_{2} 2$, HEPES 5, and $\mathrm{D}$-glucose 10, $\mathrm{pH}$ adjusted to 7.4. Cells were maintained either in the standard solution or in the presence of carbenoxolone (CBX, $50 \mu \mathrm{M})$ or Gap26 peptide $(100 \mu \mathrm{M})$ for $5 \mathrm{~min}$ and then exposed to $5 \mu \mathrm{M} \mathrm{EtBr}$ for $10 \mathrm{~min}$ at room temperature (RT). Cells were then washed with the same buffer and fixed with $4 \%$ paraformaldehyde in PBS. Fixed cells were examined at $40 \times$ with a confocal laser-scanning microscope (Leica SP5). Stacks of 10 consecutive confocal images taken at $0.5 \mu \mathrm{m}$ intervals were acquired. Six images were captured for each experimental condition per animal. Images of EtBr uptake were analyzed with ImageJ.

Electrophysiological recordings of hemichannel currents in cultured astrocytes. Secondary astrocyte cultures were harvested by trypsin-EDTA and replated on glass coverslips for at least $3 \mathrm{~h}$ before electrophysiological recordings. This treatment yields round-shaped solitary astrocytes for subsequent whole-cell recording experiments. The bath solution was composed of the following (in mM): $\mathrm{NaCl} 130, \mathrm{CsCl} 10, \mathrm{MgCl}_{2} 1, \mathrm{CaCl}_{2}$ 1.8 , HEPES 10, pH 7.4; the pipette solution contained the following (in mM): $\mathrm{CsCl} 130$, Na-aspartate $10, \mathrm{CaCl}_{2} 0.26, \mathrm{MgCl}_{2} 1$, EGTA 2, tetraethylammonium (TEA)-Cl 7, and HEPES 5, $\mathrm{pH}$ 7.2. Pipette $\left[\mathrm{Ca}^{2+}\right]$ was $50 \mathrm{~nm}$ as calculated with Webmax software (http://www.stanford.edu/ $\sim$ cpatton/webmaxcS.htm), the composition of the $200 \mathrm{~nm}$ pipette $\left[\mathrm{Ca}^{2+}\right]$ solution was calculated with the same software. Single-channel currents were recorded with an EPC 7 PLUS patch-clamp amplifier (HEKA Electronik). The holding potential was $-80 \mathrm{mV}$ and pulse duration of voltage 
steps to various potentials was $15 \mathrm{~s}$ long. Voltage ramp stimulation ranged from -70 to +70 $\mathrm{mV}$ and was applied over a $10 \mathrm{~s}$ time period. Currents were filtered by a 7-pole Bessel lowpass filter at $1 \mathrm{kHz}$ cutoff frequency. Data were digitized at $2 \mathrm{kHz}$ using a NI USB-6221 data acquisition device (National Instruments) and WinWCP acquisition software designed by Dr. J. Dempster (University of Strathclyde, UK). Hemichannel membrane charge transfer $\left(Q_{m}\right)$ was calculated by integrating the unitary current traces over the duration of the voltage step as follows:

$$
Q_{m}=\int i d t
$$

\section{Electrophysiology recordings in acute}

\section{cortical slices}

Slice preparation and recording conditions. Mice from postnatal day 21 (P21) to P28 (P0 being the day of birth) were killed by decapitation and the PFC was rapidly dissected in ice-cold oxygenated $\left(95 \% \mathrm{O}_{2}-5 \% \mathrm{CO}_{2}\right)$ solution containing the following (in $\mathrm{mm}$ ): $\mathrm{NaCl} 83$, $\mathrm{NaHCO}_{3} 26.2, \mathrm{NaH}_{2} \mathrm{PO}_{4} 1, \mathrm{KCl} 2.5, \mathrm{MgSO}_{4}$ 3.3, $\mathrm{CaCl}_{2}$ 0.5, sucrose 70, and D-glucose 22, $\mathrm{pH} 7.3,315 \mathrm{mOsm}$. Coronal slices $(250 \mu \mathrm{m})$ were cut in the same solution using a vibratome (Microm HM 650V; Thermo Fisher), incubated for $30 \mathrm{~min}$ at $34^{\circ} \mathrm{C}$ in the standard artificial CSF solution (ACSF) and stored at room temperature until use. All solutions were perfused continuously and oxygenated with a mixture of $95 \% \mathrm{O}_{2}$ and $5 \% \mathrm{CO}_{2}$. Slices were then placed in a submerged recording chamber mounted on an upright microscope (Zeiss Axioskop FS) equipped for infrared differential interference contrast microscopy and epifluorescence. They were perfused continuously with the standard oxygenated ACSF containing the following (in mM): $\mathrm{NaCl} 124, \mathrm{NaHCO}_{3} 26, \mathrm{KCl} 3, \mathrm{NaH}_{2} \mathrm{PO}_{4} 1.25, \mathrm{MgCl}_{2} 1.3$, $\mathrm{CaCl}_{2}$ 2, and D-glucose 20, pH 7.4 at RT at $2 \mathrm{ml} / \mathrm{min}$. Whole-cell voltageclamp recordings for pyramidal neurons were performed with borosilicate glass pipettes ( $3-5 \mathrm{M} \Omega$ in bath) containing the following (in $\mathrm{mm}$ ): Cs-methylsulfonate 115, HEPES 10, ATP 4, CsCl 20, GTP 0.4, EGTA 10, adjusted to $\mathrm{pH} 7.4$ with $\mathrm{CsOH}, 281 \mathrm{mOsm}$. Whole-cell voltage-clamp recordings of astrocytes were performed with borosilicate glass pipettes (6-7 $\mathrm{M} \Omega$ in bath) containing the following (in $\mathrm{mm}$ ): K-gluconate 105, $\mathrm{KCl} 30$, HEPES 10, phosphocreatine 10, ATP-Mg 4, GTPTris 0.3, and EGTA 0.3, pH 7.4, adjusted to pH 7.4 with $\mathrm{KOH}, 290$ mOsm. In $\mathrm{Ca}^{2+}$ clamp experiments, $0.45 \mathrm{~mm}$ EGTA and $0.14 \mathrm{~mm} \mathrm{CaCl}_{2}$ were added to the control intracellular astrocyte solution to maintain intracellular free $\mathrm{CaCl}_{2}$ at a steady-state concentration of $50-80 \mathrm{~nm}$ (calculation by WebMaxChelator; adapted from Henneberger et al., 2010). When required, the currently most effective serine racemase inhibitor L-erytho-3hydroxyaspartate (HOAsp) (Wako Chemicals; $K_{\mathrm{i}}=49 \mu \mathrm{M}$ ) was added to the astrocyte intracellular solution (Strisovsky et al., 2005). Whole-cell currents were recorded with a MultiClamp 700B amplifier (Molecular Devices), sampled with a Digidata 1322A Interface (10 kHz sampling, 2 $\mathrm{kHz}$ filtering), and the analysis was performed with pClamp9 software (Molecular Devices). Series resistances were compensated at $80 \%$ for pyramidal cells and astrocytes. Input resistance was measured in voltageclamp mode by applying hyperpolarizing voltage pulses $(-10 \mathrm{mV}, 150$ $\mathrm{ms}$ ) from a holding potential of $-60 \mathrm{mV}$ for pyramidal neurons and from a holding potential of $-80 \mathrm{mV}$ for astrocytes. Only pyramidal neurons with a resting membrane potential more negative than $-55 \mathrm{mV}$ and astrocytes with a resting membrane potential more negative than $-75 \mathrm{mV}$ were kept for further analysis. Access resistance of the recording pipette was tested at the beginning and the end of each experiment, all recordings with an access resistance $\left(R_{\mathrm{a}}\right)>25 \mathrm{M} \Omega$ or $>20 \%$ change between the beginning and the end of the experiment were excluded from analysis. Electrical stimuli (1-10 $\mu \mathrm{A}, 0.2 \mathrm{~ms}$ duration) were deliv- ered (ISO-Flex A.M.P.I.) extracellularly in layer 2-3 (L2-3) using $1 \mathrm{M} \Omega$ glass electrodes filled with the external solution described above. The stimulation intensity corresponded to $50 \%$ of the maximum response. For analysis, at least five consecutive traces were averaged.

\section{Dye coupling experiments in astrocytes}

Cells were identified as astrocytes based first on their morphology and second on electrophysiological properties (see above). The pipette (3-8 $\mathrm{M} \Omega$ ) solution contained the following (in $\mathrm{mM}$ ): $\mathrm{K}$-gluconate $105, \mathrm{KCl} 30$, HEPES 10, phospho-creatine Tris 10, ATP- $\mathrm{Mg}^{2+} 4$, GTP-Tris 0.3, EGTA 0.3 , adjusted to $\mathrm{pH} 7.4$ with $\mathrm{KOH}$, and sulforhodamine $\mathrm{B}(1 \mathrm{mg} / \mathrm{ml} ; 559$ $\mathrm{Da}$; Invitrogen). Input resistance $\left(R_{\mathrm{in}}\right)$ was measured in voltage-clamp mode by applying hyperpolarizing voltage pulses $(10 \mathrm{mV}, 150 \mathrm{~ms})$ from a holding potential of $-80 \mathrm{mV}$. To assess the level of gap junction coupling, sulforhodamine B was added to the pipette solution before each experiment. Recorded cells were loaded passively with the dye for $10 \mathrm{~min}$ in current-clamp mode. The duration of the whole-cell recording was kept constant to allow comparison among experiments. Intercellular diffusion of sulforhodamine B was captured thereafter with the CCD camera (Pixelfly QE; Cook) on different focal planes and the number of surforhodamine B-positive cells (i.e., cells dye coupled to the recorded astrocyte) was determined using ImageJ software (Liu et al., 2013).

Recording of NMDA and AMPA synaptic currents in pyramidal neurons. NMDA EPSCs were recorded in response to electrical stimulation of L2-3 after blockade of GABA $A_{A}$ receptors by picrotoxin $(100 \mu \mathrm{M})$ and AMPA receptors by NBQX $(10 \mu \mathrm{M})$ at a holding potential of $+40 \mathrm{mV}$. The NMDA EPSCs were abolished by the bath application of $(2 R)$ amino-5-phosphonovaleric acid (D/L-AP5, $50 \mu \mathrm{M}$ ), an NMDAR blocker (see Fig. 2A1). AMPA EPSCs evoked by L2-3 electrical stimulation were also recorded at a holding potential of $-70 \mathrm{mV}$ in presence of picrotoxin $(100 \mu \mathrm{M})$, a GABA A receptor blocker, and D/L-AP5 $(50 \mu \mathrm{M})$ to block NMDA EPSCs. The AMPA EPSCs were abolished by bath application of 2,3-dihydroxy-6-nitro-7-sulfamoyl-benzo[f] quinoxaline-2,3-dione (NBQX, $10 \mu \mathrm{M}$ ), a selective blocker of AMPARs (data not shown). The AMPA/NMDA ratio was measured in the same cell in the presence of picrotoxin but in the absence of NBQX.

Plasticity induction protocol. After a control period (15 min), an HFS protocol was elicited in L2-3 of the PFC with theta-burst stimulation ( 3 trains of 13 bursts applied at $5 \mathrm{~Hz}$ frequency, each burst containing 4 

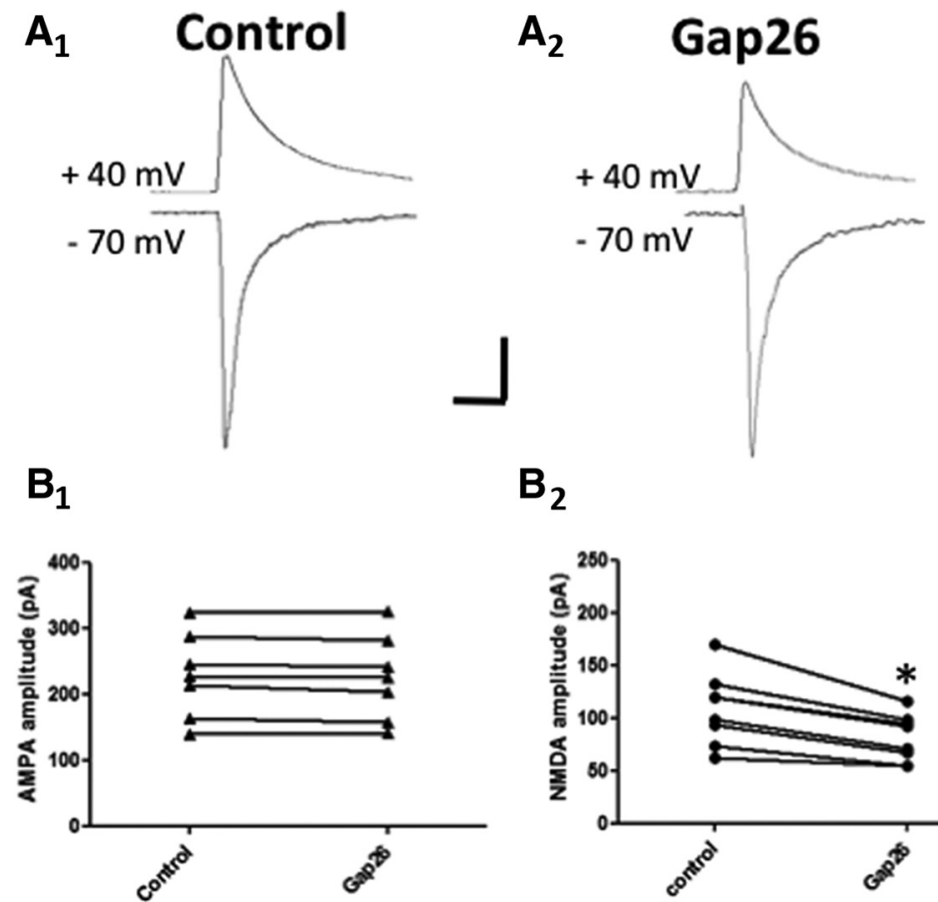

C

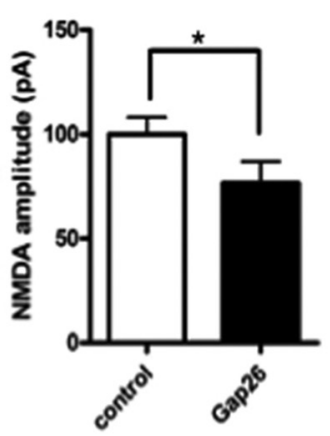

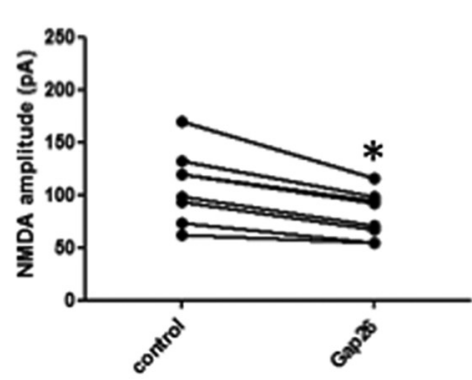

D

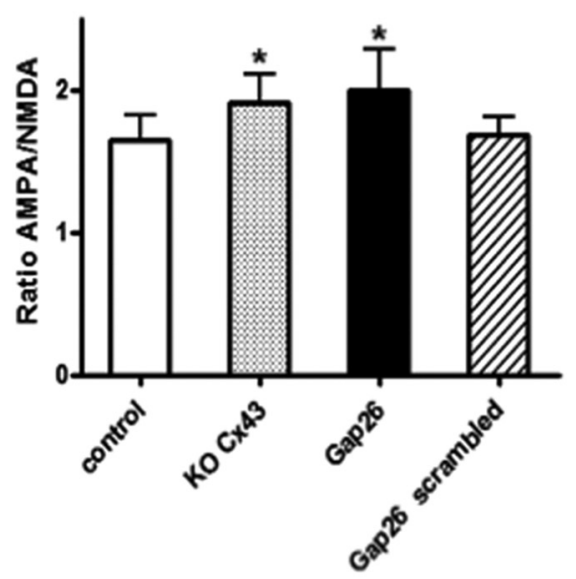

Figure 2. Inhibition of (x43 hemichannel activity in astrocytes affects NMDA EPSCs in the PFC. $\mathbf{A 1}, \mathbf{A 2}$, EPSCs (averaged from five consecutive traces) generated by stimulation in $\mathrm{L} 2 / 3$ were recorded, in the presence of picrotoxin $(100 \mu \mathrm{M})$ in pyramidal cells from L5 held at $+40 \mathrm{mV}$ or $-70 \mathrm{mV}$ to isolate NMDA and AMPA EPSCs, respectively. Scale bars, $100 \mathrm{pA}$ and $100 \mathrm{~ms}$. A1, Typical NMDA and AMPA EPSCs in control condition. A2, Typical NMDA and AMPA EPSCs in presence of Gap26. B1, B2, Differential effect of Gap26 $(200 \mu \mathrm{M})$ on the amplitude of AMPA (B1) and NMDA (B2) EPSCs. Note that there was no significant difference between control and Gap26 for AMPA currents ( $p>0.05, t$ test, $n=7$ ), whereas the amplitude of NMDA currents was significantly reduced $(p<0.05$, $t$ test, $n=7)$. $C$, Mean of NMDA EPSC amplitude in control conditions and in presence of Gap26. D, Quantification of AMPA/NMDA ratio under the indicated conditions. The AMPA/NMDA ratio was significantly increased in C $433 \mathrm{~K} 0$ mice $(p<0.05, t$ test, $n=7)$ and in presence of Gap26 ( $p<0.05, t$ test, $n=7)$, whereas the Gap26 scramble peptide had no effect $(p>0.05, t$ test, $n=7)$.

pulses at $100 \mathrm{~Hz}$, for a total duration of $2 \mathrm{~min}$ ). Then, recording of current responses in pyramidal neurons were performed after the end of the HFS protocol to be compared with the control recording. The mean amplitude of NMDA and AMPA EPSCs was measured 30 min after HFS protocol induction.

Confocal imaging of PFC acute slices. After loading pyramidal cell in L5 with biocytin ( $1 \mathrm{mg} / \mathrm{ml}$; Sigma-Aldrich) in the PFC, acute slice was fixed in $4 \%$ PFA overnight at $4^{\circ} \mathrm{C}$. Fixed PFC slices from 1-month-old hGFAPeGFP mice were examined with a confocal laser scanning microscope SP5 (Leica). To visualize the entire length of a pyramidal cell from L5 loaded with biocytin (1 mg/ml; Sigma-Aldrich) revealed by Alexa Fluor 555-conjugated steptavidin, 5 images covering L1-5 of the PFC were captured with a $20 \times$ objective. Stacks of 30 consecutive confocal optical sections at $1 \mu \mathrm{m}$ intervals were acquired sequentially (with 2 lasers 488 and $560 \mathrm{~nm}$ ) and $Z$ projections were reconstructed using Leica confocal software. Then, one image was reconstructed using the photomerge function of Adobe Photoshop software. To visualize the morphology of one astrocyte expressing eGFP, a stack of 30 optical sections taken at $0.5 \mu \mathrm{m}$ intervals were acquired with a $63 \times$ objective and $Z$ projection reconstructed.

\section{Drugs and peptides}

The following drugs were used in this study: the mimetic peptide Gap26 (amino acid sequence VCYDKSFPISHVR; purity, >95\%; 300 $\mu \mathrm{g} / \mathrm{ml}, 200 \mu \mathrm{m}$; Thermo Fisher Scientific) and a scrambled peptide containing the same amino acids as the Gap26 (amino acid sequence PSFDSRHCIVKYV; purity, >95\%; 300 $\mu \mathrm{g} / \mathrm{ml}, 200 \mu \mathrm{M}$; Thermo Fisher Scientific). To avoid peptide degradation, peptides were diluted in oxygenated ACSF 2 min before application on the slices. To test the impact on $\mathrm{Cx} 43$ hemichannel function, analysis was performed within the first 10-15 min of recording after peptide exposure except for the LTP experiments. All chemicals used for electrophysiology experiments were obtained from Sigma-Aldrich except for D/L-AP5, NBQX, Ro 25-6981 maleate, $\mathrm{D}$-serine, and 7-chlorokynurenic acid, which were purchased from R\&D Systems.

\section{Statistical analysis}

For each data group, results are expressed as mean \pm SEM and $n$ refers to the number of independent experiments. Unpaired onetailed student test was used. Differences are considered significant at ${ }^{*} p<0.05,{ }^{* *} p<$ 0.01 , and ${ }^{* * *} p<0.001$. GraphPad Prism 5 software was used for calculations. One-way variance analysis on ranks with Dunn's post test was used for multiple comparisons in the bar charts of Figure 5, $E$ and $F$.

\section{Results}

Cx43 hemichannel activity in astrocytes impacts NMDAR-mediated synaptic currents recorded from pyramidal neurons in prefrontal cortical slices The involvement of $\mathrm{Cx} 43$ hemichannels in the modulation of glutamatergic synaptic currents was investigated in PFC L5 pyramidal cells (L5PCs) in response to L2/3 stimulation (Fig. $1 A-C$ ). For this purpose, we first used the mimetic peptide Gap26 (Chaytor et al., 1997) to specifically reduce $\mathrm{Cx} 43$ hemichannel function in astrocytes (Giaume et al., 2013) from ex vivo PFC slice preparation. This mimetic peptide contains an amino acid sequence found in the first extracellular loop of $\mathrm{Cx} 43$ and its interaction with $\mathrm{Cx} 43$ prevents hemichannel opening in astrocytes as shown previously by dye uptake assays (Retamal et al., 2007; Chever et al., 2014; Abudara et al., 2015) and electrophysiological recording of Cx43transfected cells (Desplantez et al., 2012; Wang et al., 2012). At 2 weeks of age, $\mathrm{Cx} 43$ is not expressed by neurons (Nagy and Rash, 2000; Genoud et al., 2015), microglial cells, or cells of the oligo- 
dendroglial lineage (Nagy and Rash, 2000); therefore, the application of Gap26 is expected to target hemichannels in astrocytes selectively. We first looked at glutamatergic postsynaptic responses triggered by L2/3 stimulation and isolated excitatory AMPA and NMDA currents by recording them at two holding potentials, -70 and $+40 \mathrm{mV}$, respectively, in presence of picrotoxin (Fig. 2A1,A2). In such conditions, we observed that the acute application of Gap26 (200 $\mu \mathrm{M})$ had no effect on the AMPA EPSC amplitude ( $p>0,05, t$ test, $n=7$; Fig. 2A2,B1). In contrast, the average NMDA EPSC amplitude was significantly reduced by Gap26 (22 $\pm 3 \%, p<0.05, t$ test, $n=7$; Fig. $2 A 2, B 2, C)$, leading to a significant increase of the AMPA/NMDA ratio ( $24 \pm 4 \%$; $p<$ $0.05, t$ test, $n=7)$. Control experiments using the scrambled Gap26 peptide $(200 \mu \mathrm{M})$ showed no effect on the AMPA/NMDA ratio ( $p>0.05, t$ test, $n=7$ ). Finally, we found that the AMPA/ NMDA ratio was also significantly higher in wild-type than in $C \times 43^{\mathrm{f} / / \mathrm{fl}}: G F A P$-cre $(\mathrm{Cx} 43 \mathrm{KO})$ cortical slices $(22 \pm 3 \% ; p<0.05$, $t$ test, $n=7$; Fig. $2 D$ ). Altogether, these observations indicate that Cx43 hemichannel activity in astrocytes affects glutamatergic transmission by reducing specifically NMDA synaptic currents in L5PCs of the PFC.

\section{NMDA synaptic currents are modulated by $D$-serine release} associated with $\mathrm{Cx} 43 \mathrm{HC}$ activity in astrocytes

We next aimed at determining whether the reduction in NMDA currents due to $\mathrm{Cx} 43$ hemichannel activity was linked to gliotransmission. Indeed, because Gap26 did not affect AMPA currents yet NMDA currents were reduced and because astrocytes represent a potential source for D-serine (Gundersen et al., 2015), we hypothesize that Cx43 hemichannel activity may be involved in the process of $\mathrm{D}$-serine release by astrocytes. First, the NMDA nature of currents recorded at $+40 \mathrm{mV}$ was confirmed by its complete blockade ( $95 \pm 4 \% ; n=7, t$ test, $p<0.001)$ in the presence of D/L-AP5 $(50 \mu \mathrm{M})$, an NMDAR blocker (Fig. 3A1,B). Second, we tested the effect of several concentrations of D-serine on NMDA EPSCs in presence of Gap26 (Fig. 3B). In this set of experiments, we observed as indicated above that bath application of Gap26 $(200 \mu \mathrm{M})$ induced a significant decrease of NMDA EPSCs ( $23 \pm 3 \%$ of control; $p<0.05, t$ test, $n=9)$ ). This inhibition was not rescued by $5 \mu \mathrm{M}$-serine $(p>0.05, t$ test, $n=7)$, whereas 10 and $100 \mu \mathrm{M} \mathrm{D}$-serine were found to reverse the effect of Gap26 ( $p<0.05, t$ test, $n=6$ and 7, respectively; Fig. 3A2,B). As a whole, these results suggest that $\mathrm{D}$-serine release is correlated to $\mathrm{Cx} 43$ hemichannel activity in astrocytes and thus contributes to modulate NMDA EPSCs in L5PCs of the PFC.

Cx43 hemichannel activity is controlled by intracellular $\mathrm{Ca}^{2+}$ concentration in cultured astrocytes

Calcium signaling in astrocytes involves complex pathways that participate in neuroglial interaction dynamics (Scemes and Giaume, 2006; Khakh and McCarthy, 2015; Bazargani and Attwell, 2016). Cx43 hemichannels have been demonstrated to open with a modest increase of the intracellular $\mathrm{Ca}^{2+}$ concentration $\left(\left[\mathrm{Ca}^{2+}\right]_{\mathrm{i}}\right)$; upon further increasing $\left[\mathrm{Ca}^{2+}\right]_{\mathrm{i}}(>500 \mathrm{nM})$, the channels close again, resulting in a bell-shaped "convex-up" response curve (De Vuyst et al., 2009; Wang et al., 2012; Bol et al., 2017). However, most of these properties were obtained from cell expression systems or cardiomyocytes; here, we determined whether astroglial $\mathrm{Cx} 43$ hemichannels could also be activated by $\left[\mathrm{Ca}^{2+}\right]_{\mathrm{i}}$ elevation. We first tested whether increasing $\left[\mathrm{Ca}^{2+}\right]_{\mathrm{i}}$ activated endogenous $\mathrm{Cx} 43$ hemichannels in cultured astrocytes by using the EtBr uptake assay taken as an index of hemichannel
$\mathbf{A}_{1}$

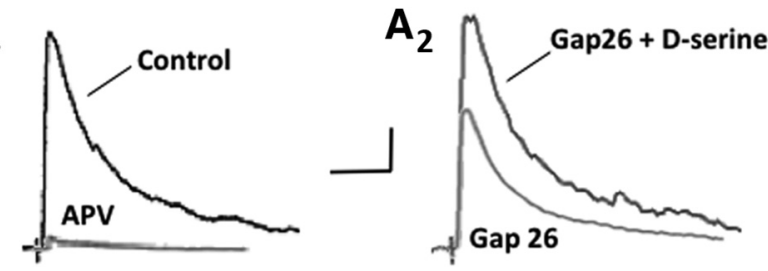

B

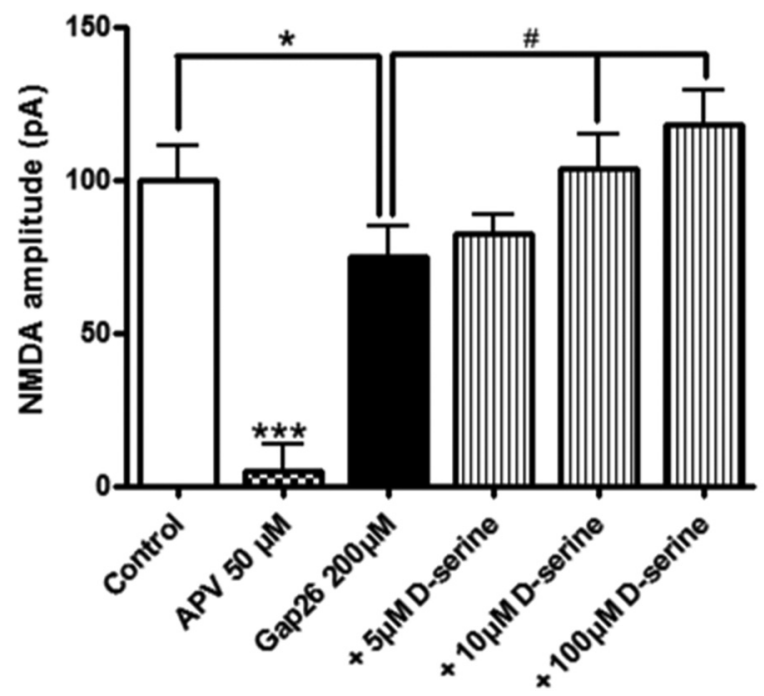

Figure 3. Modulation of NMDA EPSCs in pyramidal cells by D-serine involves astrocyte hemichannel activity. $\boldsymbol{A}$, $\boldsymbol{A 2}$, Typical recording of NMDA EPSCs at $+40 \mathrm{mV}$ (scale bars, $100 \mathrm{pA}$ and $100 \mathrm{~ms}$ ) in presence of picrotoxin $(100 \mu \mathrm{m})$ and NBQX $(10 \mu \mathrm{M})$. A1, NMDA EPSCs (averaged from 5 consecutive traces) were abolished by the NMDAR blocker D/L APV $(p<0.001, t$ test, $n=7)$. A2, NMDA EPSCs were significantly decreased in presence of Gap26 $(p<0.05, t$ test, $n=9)$ and this effect was rescued by adding D-serine $(100 \mu \mathrm{M})$ to the extracellular solution. $B$, Graph summarizing the relative NMDA EPSC amplitude of the samples shown in $A$ and $\boldsymbol{B}$ and for several concentration of $D$-serine in the external solution. Note that the rescue of Gap26 inhibitory effect became statistically significant for 10 and $100 \mu \mathrm{M}$ D-serine $(p<0.05, t$ test, $n=7)$.

activity (Giaume et al., 2012). As illustrated in Figure 4, treatment of Fluo-4/AM-loaded astrocytes with ionomycin $(1 \mu \mathrm{M})$ elicited a rapid increase in $\left[\mathrm{Ca}^{2+}\right]_{i}$ that reached a plateau after $90 \mathrm{~s}$ (Fig. $4 B)$. In such conditions, we observed that EtBr uptake was increased by $102 \pm 14 \%$ ( $p<0.05$, one-way ANOVA with Tukey's test, $n=3$ ) in the presence of ionomycin and that EtBr uptake returned to basal level when either CBX $(50 \mu \mathrm{M})$ or Gap26 $(200 \mu \mathrm{M})$ was added in presence of ionomycin (Fig. 4A1-A3,C). These results indicate that an increase of $\left[\mathrm{Ca}^{2+}\right]_{\mathrm{i}}$ in astrocytes activates $\mathrm{Cx} 43$ hemichannels.

We next performed patch-clamp experiments on single astrocytes isolated from astrocyte cell cultures and recorded in wholecell mode, allowing control of $\left[\mathrm{Ca}^{2+}\right]_{\mathrm{i}}$ by changing the $\mathrm{Ca}^{2+}$ concentration in the pipette solution. In the control $50 \mathrm{~nm}$ $\left[\mathrm{Ca}^{2+}\right]_{\mathrm{i}}$ condition, voltage steps from a holding potential of -80 $\mathrm{mV}$ to a range of potentials up to $+50 \mathrm{mV}$ did not trigger any hemichannel opening activity (Fig. $5 \mathrm{~A}$ ). With $\left[\mathrm{Ca}^{2+}\right]_{\mathrm{i}}$ set to $200 \mathrm{nM}$, clear current activities appeared in the traces. Activities were most prominent at $+50 \mathrm{mV}$ as observed in other cell types (Wang et al., 2012). Interestingly, single-channel opening events were also observed at potentials in the -70 to $-30 \mathrm{mV}$ range (Fig. $5 A$ ). Absence of unitary current activity at $50 \mathrm{~nm}\left[\mathrm{Ca}^{2+}\right]_{\mathrm{i}}$ and its appearance at both negative and positive potentials with $200 \mathrm{~nm}$ $\left[\mathrm{Ca}^{2+}\right]_{i}$ were also observed when electrical stimulation was done with voltage ramps (Fig. $5 B$ ). The presence of single channel activities at negative and positive voltages allowed us to construct 


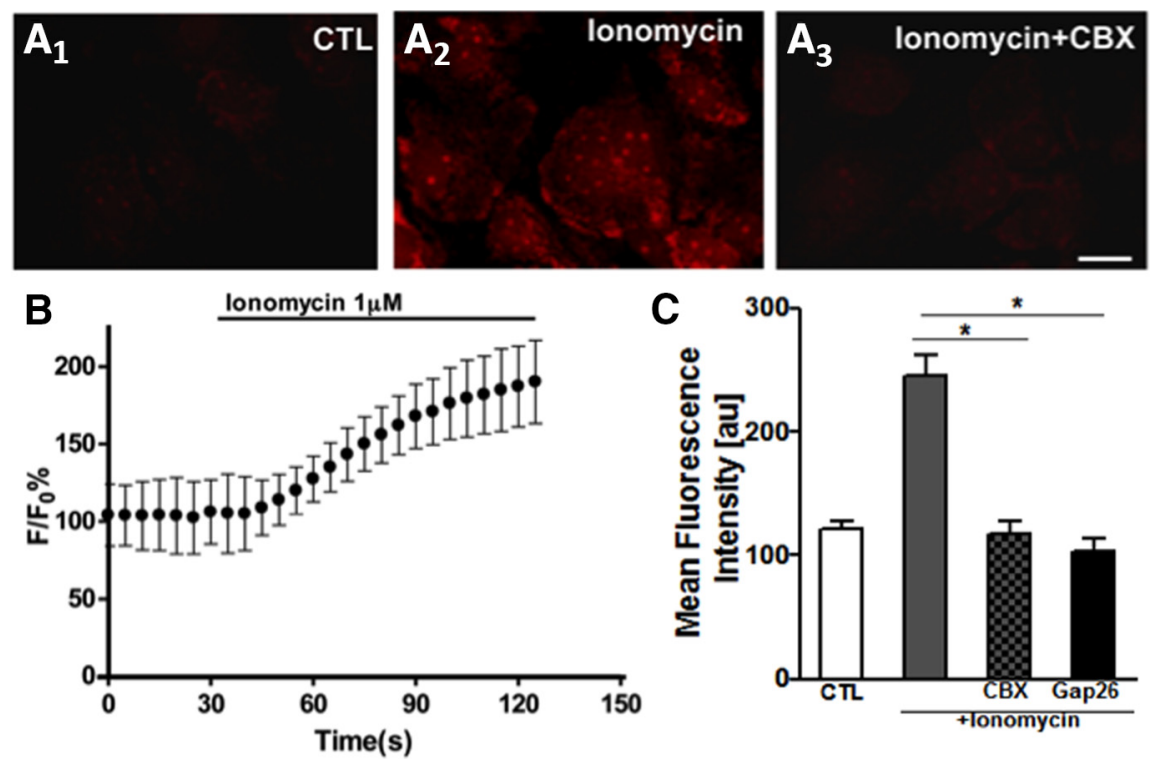

Figure 4. Activation of $\mathrm{Cx} 43$ hemichannel in cultured cortical astrocytes is $\mathrm{Ca}^{2+}$ dependent. $\boldsymbol{A} \mathbf{1}-\boldsymbol{A} \mathbf{3}$, Fluorescent images of $\mathrm{EtBr}$ uptake in cultured astrocytes in control condition (CTL), after treatment with ionomycin (1 $\mu \mathrm{M})$, and after treatment with ionomycin plus $\mathrm{CBX}(50 \mu \mathrm{m})$. Scale bar, $5 \mu \mathrm{m}$. Note that, whereas in control conditions, the uptake of EtBr was not observed $(\boldsymbol{A 1})$, it became detected in the presence of the $\mathrm{Ca}^{2+}$ ionophore ionomycin $(1 \mu \mathrm{m} ; \mathrm{A2})$ and was prevented by adding $\mathrm{CBX}$ to ionomycin (A3). $\boldsymbol{B}$, Time-dependent increase in resting $\left[\mathrm{Ca}^{2+}\right]_{\mathrm{i}}$ recorded in astrocytes loaded with Fluo-4/AM and treated with ionomycin. Error bars indicate mean \pm SD, $n>100$ astrocytes for the same experiment. C, Histogram showing EtBr uptake expressed as the mean fluorescence intensity per astrocyte nucleus in control and after treatment with ionomycin. The increase in EtBr uptake triggered by ionomycin was blocked by either CBX (50 $\mu \mathrm{m})$ or Gap26 (100 $\mu \mathrm{m} ; p<0.05$, Student's $t$ test, $n=3$ independent cultures).

an $I-V$ plot of unitary current amplitudes, which was characterized by a slope conductance of $230 \mathrm{pS}$, a typical value for the single-channel conductance of $\mathrm{Cx} 43$ hemichannels (Fig. 5C). We next constructed all point histograms of unitary current activities at negative $(-70$ to $-30 \mathrm{mV})$ and positive potentials $(+30$ to $+50 \mathrm{mV})$. These graphs (Fig. 5D) demonstrated a singlechannel conductance in the range of the slope conductance obtained from the $I-V$ plot (Fig. 5C). Importantly, Gap26 (200 $\mu \mathrm{M})$ inhibited the unitary current activities at negative and positive potentials in the traces (Fig. 5A) and in the histograms (Fig. 5D). We further quantified the inhibitory effect of Gap26 on unitary current activities by calculating the charge transfer associated with unitary hemichannel opening activity. Such analysis demonstrated very low hemichannel charge transfer at $50 \mathrm{nM}\left[\mathrm{Ca}^{2+}\right]_{\mathrm{i}}$, which was significantly increased at $200 \mathrm{nM}\left[\mathrm{Ca}^{2+}\right]_{\mathrm{i}}$ and was reduced to baseline level by Gap26 for both positive and negative voltages (see Fig. $5 E$ for data at $-70 \mathrm{mV}$ and Fig. $5 F$ for data at $+50 \mathrm{mV}$ ). The traces of the voltage-ramp experiments shown in Figure $5 B$ suggest that Gap26 also affects the current with unresolved unitary components. To determine whether such effect is consistent, we verified whether Gap26 influences the clamping current at a given command voltage. At $+50 \mathrm{mV}$, Gap26 indeed significantly inhibited the clamping current $\left(50 \mathrm{nM}\left[\mathrm{Ca}^{2+}\right]_{\mathrm{i}}\right.$ : $166 \pm 37 \mathrm{pA}, 200 \mathrm{~nm}\left[\mathrm{Ca}^{2+}\right]_{\mathrm{i}}: 263 \pm 42 \mathrm{pA}$ and $200 \mathrm{nM}\left[\mathrm{Ca}^{2+}\right]_{\mathrm{i}}+$ Gap26: $123 \pm 27 \mathrm{pA} ; n=6 ; p<0.05$ one-way ANOVA), whereas there were no significant differences at $-70 \mathrm{mV}\left(50 \mathrm{nM}\left[\mathrm{Ca}^{2+}\right]_{\mathrm{i}}\right.$ : $-82.8 \pm 33 \mathrm{pA}, 200 \mathrm{nM}\left[\mathrm{Ca}^{2+}\right]_{\mathrm{i}}:-81.1 \pm 20 \mathrm{pA}$ and $200 \mathrm{nM}$ $\left[\mathrm{Ca}^{2+}\right]_{\mathrm{i}}+$ Gap26: $\left.-80.9 \pm 33 \mathrm{pA} ; n=6\right)$. The Gap26 effect at $+50 \mathrm{mV}$ may result from long hemichannel opening events (not associated with channel transition events during the time window of the recording), which require a significant increase in the clamping current.
Clamp of $\left[\mathrm{Ca}^{2+}\right]_{\mathrm{i}}$ and inhibition of hemichannel activity in astrocytes reduce LTP of NMDA and AMPA synaptic currents in the PFC

Several studies have pointed out the importance of hippocampal astrocyte $\left[\mathrm{Ca}^{2+}\right]_{\mathrm{i}}$ signaling in regulating $\mathrm{D}$-serine release and LTP (Henneberger et al., 2010; Kang et al., 2013). However, the implication of astrocyte $\left[\mathrm{Ca}^{2+}\right]_{\mathrm{i}}$ in LTP remains under discussion (Bazargani and Attwell, 2016). Because we have demonstrated that increasing $\left[\mathrm{Ca}^{2+}\right]_{\mathrm{i}}$ activates $\mathrm{Cx} 43$ hemichannels in astrocytes, we decided to test in the PFC whether their activation plays a role in LTP of NMDAR EPSCs. For this purpose, we recorded NMDAR EPSCs in response to a HFS protocol in L5PCs and clamped $\left[\mathrm{Ca}^{2+}\right]_{\mathrm{i}}$ in astrocytes. To achieve the $\left[\mathrm{Ca}^{2+}\right]_{\mathrm{i}}$ clamp in the astroglial network, we used a previously reported intrapipette solution with EGTA and 50-80 $\mathrm{nM} \mathrm{Ca}^{2+}$ (Henneberger et al., 2010) and a dual recording with a L5PC and a neighbor astrocyte from eGFPhGFAP mice. A recent study (De Nardo et al., 2015) indicates that, in the mouse at the age studied, PFC L2/3 (where the stimulating electrode was located; Fig. $1 A$ ) provides a major source of excitatory inputs to L5 (where the patched pyramidal neuron and the astrocyte were located; Fig. 1A). This presumably concerns the soma and the proximal dendrite of the pyramidal cells. In addition, the extent of dye coupling (studied with sulforhodamine B) between astrocytes was $53 \pm 3$ cells $(n=$ 10 ) after $10 \mathrm{~min}$ of whole-cell recording (Fig. $1 B$ ) and the averaged diameter size of an astrocyte domain was $58 \pm 1 \mu \mathrm{m}$ $(n=12)$ based on measurements of eGFP-positive astrocytes located in L5 (Fig. 1C). Therefore, taking into account these features, we considered that after $30 \mathrm{~min}$ of dual recording, the $\left[\mathrm{Ca}^{2+}\right]_{\mathrm{i}}$ clamp in astrocytes was achieved in L5 astrocytes that were in the vicinity of L5PC synapses activated by the stimulation of input coming from $\mathrm{L} 2 / 3$.

HFS is known to induce important glutamate release and to potentiate AMPA and NMDA EPSCs (Nicoll and Schmitz, 2005) such that LTP of NMDAR EPSCs is observed in response to HFS both in the hippocampus (Harney et al., 2006) and in the PFC (Zhao et al., 2005). First, we separately recorded in voltage-clamp mode NMDA EPSCs at $+40 \mathrm{mV}$ or AMPA EPSCs at $-70 \mathrm{mV}$ before and after applying a HFS protocol in L2/3 of the PFC (see Materials and Methods). This procedure induced a persistent potentiation of NMDA and AMPA EPSCs that lasted at least 40 min (Figs. 6,7, respectively). NMDA and AMPA EPSCs were measured $30 \mathrm{~min}$ after HFS because it has been reported that Gap26 starts to have an effect on gap junction communication after 30 min exposure in HeLa cells (Desplantez et al., 2012) and hours in C6 glioma cells (Decrock et al., 2009). In these conditions, NMDA EPSCs were found to be significantly enhanced (Fig. $6 A 1, B, C$ ) by $48 \pm 5 \%$ compared with control before HFS $(p<0.01, t$ test, $n=7)$. However, when the $\left[\mathrm{Ca}^{2+}\right]_{\mathrm{i}}$-clamp of the astroglial network was performed before the HFS protocol, potentiation of NMDA EPSCs compared with control before the HFS was not significantly induced $(18 \pm 5 \%$ of potentiation 
A

$50 \mathrm{nM}\left[\mathrm{Ca}^{2+}\right]_{\mathrm{i}}$

$200 \mathrm{nM}\left[\mathrm{Ca}^{2+}\right]_{\mathrm{i}}$

$200 \mathrm{nM}\left[\mathrm{Ca}^{2+}\right]_{\mathrm{i}}$

Gap26

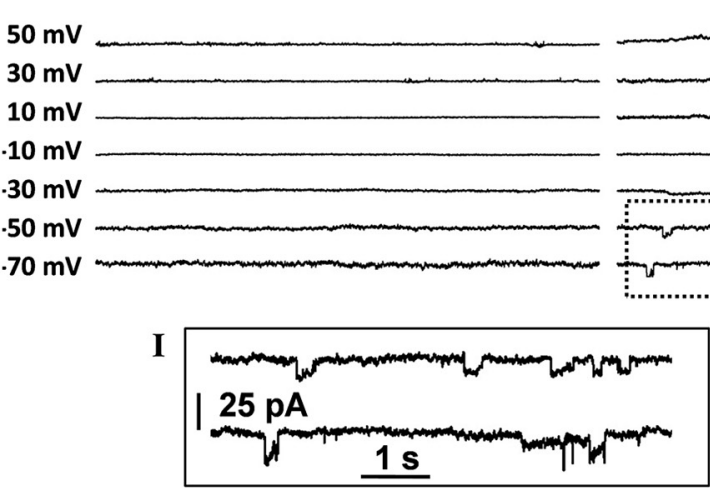

B

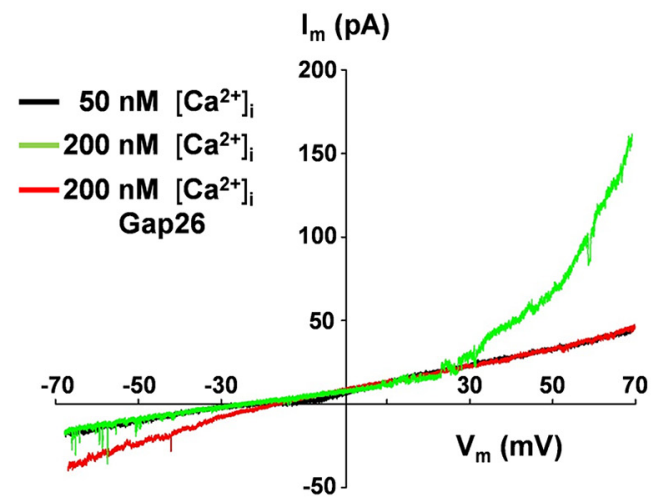

II

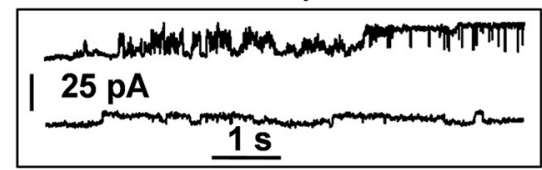

C

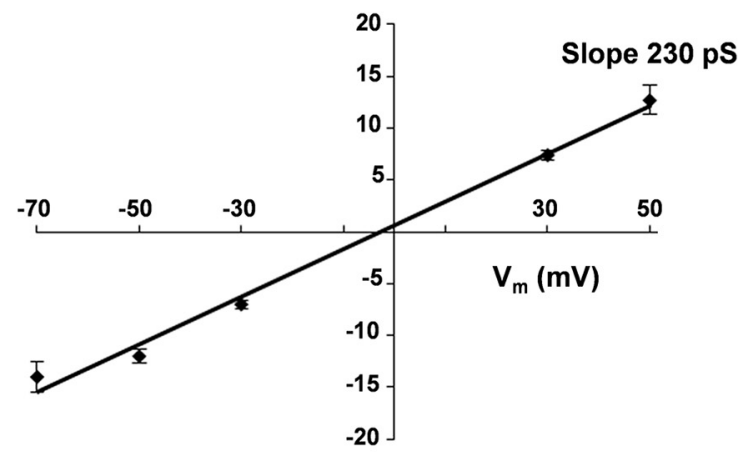

D

Negative $V_{m}$

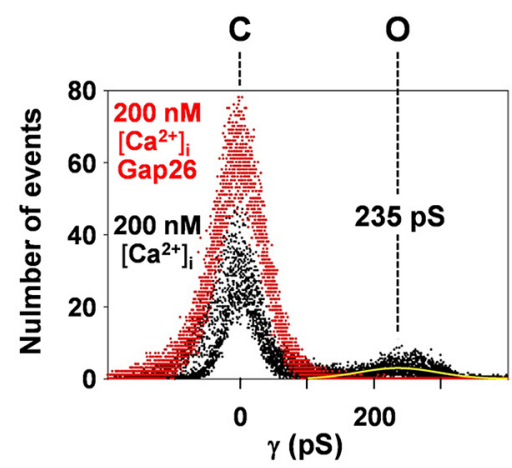

E

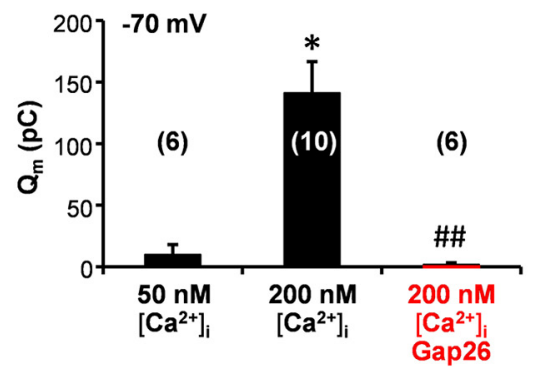

Positive $\mathrm{V}_{\mathrm{m}}$
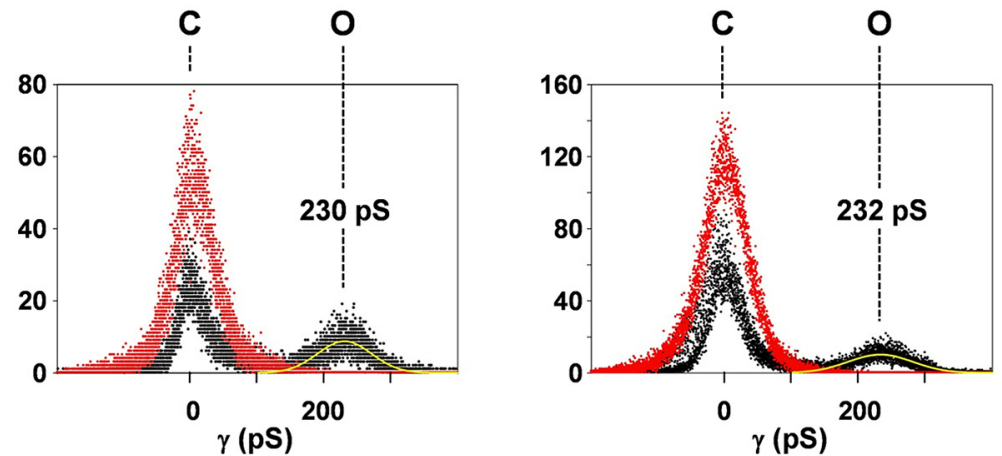

Figure 5. Patch-clamp experiments demonstrating $\mathrm{Ca}^{2+}$ activation of $\mathrm{Cx} 43$ hemichannels in cortical astrocytes. $\boldsymbol{A}$, Example traces of unitary current recordings at 50 (left) and $200 \mathrm{~nm}$ (middle) $\left[\mathrm{Ca}^{2+}\right]_{i}$ with voltage steps from $-80 \mathrm{mV}$ to the potentials indicated at left ( $15 \mathrm{~s}$ voltage steps). Current activity is apparent at $+50 \mathrm{mV}$ but also in the -70 to $-30 \mathrm{mV}$ range (activities shown at larger scale for -50 and $-70 \mathrm{mV}$ ). Gap26 $(200 \mu \mathrm{m})$ clearly inhibited current activities (right). $\boldsymbol{B}$, I-V plot demonstrating macroscopic current traces obtained from voltage-ramp experiments ( -70 to $+70 \mathrm{mV}, 10 \mathrm{~s}$ ). C, I-V plot of unitary current amplitudes from voltage-step experiments as shown in $\boldsymbol{A}$, demonstrating a single-channel slope conductance of (Figure legend continues.) 
$A_{1}$

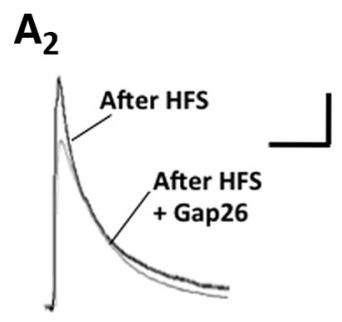

$\mathrm{A}_{3}$
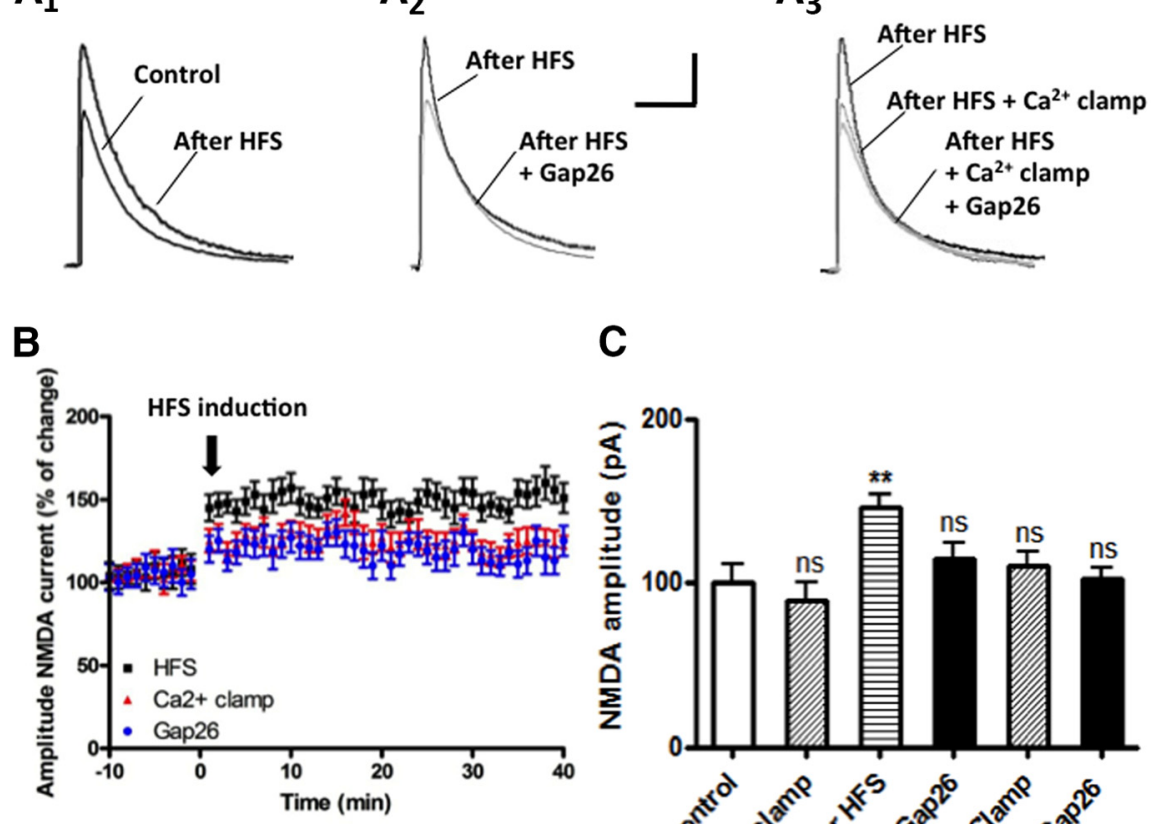

C

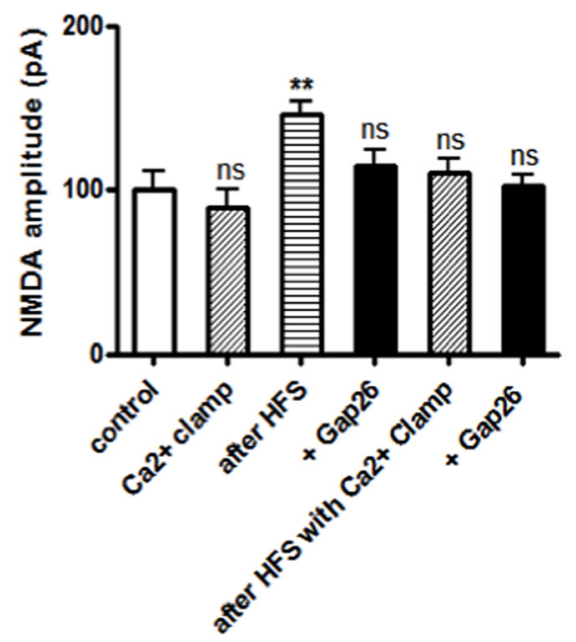

Figure 6. LTP of NMDA synaptic currents in pyramidal cells depends on $C \times 43$ hemichannel activation and $\left[\mathrm{Ca}^{2+}\right]_{\mathrm{i}}$ in astrocytes. LTP of NMDA synaptic currents in L5 was induced by HFS applied in L2/3 (see Materials and Methods and Fig. 1). A1-A3, Typical average ( $n=5$ consecutive traces) of NMDA EPSCs recorded at $+40 \mathrm{mV}$ in presence of picrotoxin $(100 \mu \mathrm{m})$ and NBQX $(10 \mu \mathrm{M})$. Scale bars, $100 \mathrm{pA}$ and $100 \mathrm{~ms}$. A1, Representative NMDA EPSCs recorded before (Control) and $30 \mathrm{~min}$ after HFS protocol. A2, NMDA EPSCs recorded $30 \mathrm{~min}$ after the HFS protocol and in presence of Gap26 (200 $\mu \mathrm{M})$. A3, NMDA EPSCs recorded 30 min after the HFS protocol and after establishing a $\mathrm{Ca}^{2+}$ clamp in the astroglial network either without or in the presence of Gap26 $(200 \mu \mathrm{M})$ in $\mathrm{Ca}^{2+}$-clamp condition. $\boldsymbol{B}$, Diagram showing the change over time in the amplitude of NMDA EPSCs measured before and after HFS protocol in control (black), in the presence of a $\mathrm{Ca}^{2+}$ clamp of the astroglial network (red), and in the presence of Gap26 (blue). C, Histogram showing the relative amplitude of NMDA EPSCs measured 30 min after the HFS protocol $(p<0.05, t$ test, $n=7)$. The LTP was significantly reduced by either $\mathrm{Ca}^{2+}$ clamp of the astroglial network or in the presence of Gap26 $(p>0.05, t$ test, $n=8)$. Note that combining $\mathrm{Ca}^{2+}$ clamp and the application of Gap26 has no additive effect $(p>0.05, t$ test, $n=7)$.
$6 A 3, B, C ; p>0.05$ compared with the condition of $\left[\mathrm{Ca}^{2+}\right]_{\mathrm{i}}$-clamp after HFS, $t$ test, $n=8)$. We also recorded AMPA EPSCs at a holding potential of $-70 \mathrm{mV}$ and found that, after HFS, they were also significantly enhanced (Fig. $7 A 1, B, C$ ) by $44 \pm 4 \%$ compared with control $(p<$ $0.01, t$ test, $n=5$ ) and that the change in AMPA EPSCs amplitude was not significant in the presence of Gap26 (200 $\mu \mathrm{M}$; $22 \pm 4 \%$ potentiation compared with the LTP control, $p>0.05$ compared with HFS control, $t$ test, $n=5$ ). In addition, AMPA currents were not modified in the presence of the Gap26 scramble peptide (Fig. $6 B, C)$. Altogether, these results indicate that LTP in the PFC is dependent on astrocyte $\left[\mathrm{Ca}^{2+}\right]_{\mathrm{i}}$, as already reported for LTP in the hippocampus for the $\left[\mathrm{Ca}^{2+}\right]_{\mathrm{i}}$ clamp (Henneberger et al., 2010) and on Cx43 hemichannel activity in astrocytes. Finally, we tested whether a selective $\left[\mathrm{Ca}^{2+}\right]_{\mathrm{i}}$ increase in astrocytes could affect the amplitude of NMDA EPSCs. For this purpose, we used endothelin-1, the receptors of which are highly expressed in astrocytes and weakly in neurons between P1 and P30 (Andersson et al., 2007) and the activation of which triggers a prolonged $\left[\mathrm{Ca}^{2+}\right]_{\mathrm{i}}$ elevation in astrocytes (Venance et al., 1998; Blomstrand et al., 1999) with no direct action on neuronal activity (Fiacco et al., 2007; Agulhon et al., 2010). When we applied endothelin-1 (10 $n \mathrm{n})$, we observed that the averaged amplitude of NMDA EPSCs had a tendency to increase (5 $\pm 1 \%$ compared with control, $p>0.4, t$ test, $n=5$ ), although this was not statistically significant (data not shown).

compared with the LTP control, $p>0.05, t$ test, $n=7$; Fig. $6 A 2, B, C)$. Interestingly, a similar effect was observed when the HFS protocol was performed in the presence of Gap26 (200 $\mu \mathrm{M} ; 21 \pm 7 \%$ potentiation compared with the LTP control, $p>$ $0.05, t$ test, $n=7)$. Indeed, in the presence of the mimetic peptide, LTP of NMDA EPSCs was not significantly induced (Fig. $6 A 2, B, C)$. In both cases, NMDA currents were not potentiated by HFS, as already reported for LTP in the hippocampus for the $\left[\mathrm{Ca}^{2+}\right]_{\mathrm{i}}$-clamp condition (Henneberger et al., 2010). Moreover, Gap26 had no additive effect when the HFS was applied after establishing the $\left[\mathrm{Ca}^{2+}\right]_{\mathrm{i}}$-clamp in the astroglial network (Fig.

(Figure legend continued.) $230 \mathrm{pS}(n=5)$. D, All point histograms constructed from unitary currents at negative $(-70$ to $-30 \mathrm{mV})$, positive $(+30$ to $+50 \mathrm{mV})$, and combined negative/ positive voltages. Single channel conductances are indicated above each peak of the distributions and were determined from the fitted Gaussian curves shown in yellow. Gap26 (red) suppressed all unitary opening events and shifted the activity distribution to the closed state (data from five different experiments). $\boldsymbol{E}, \boldsymbol{F}$, Average $Q_{\mathrm{m}}$ data for voltage steps to $+50 \mathrm{mV}$ ( $n=$ 5). Asterisks indicate significant differences compared with the $50 \mathrm{~nm}\left[\mathrm{Ca}^{2+}\right]_{i}$ condition; hashtags indicate significant differences compared with the $200 \mathrm{~nm}\left[\mathrm{Ca}^{2+}\right]_{\mathrm{i}}$ condition (one symbol $p<0.05$; two symbols $p<0.01$ ). All recordings were obtained from isolated replated primary culture of astrocytes (see Materials and Methods).

\section{D-serine release associated with hemichannel activity in} astrocytes modulates the potentiation of NMDA synaptic currents in the PFC

We investigated whether D-serine release was associated with an increase in hemichannel activity in astrocytes during the LTP protocol. To determine whether D-serine produced by astrocytes was involved in the LTP of NMDA EPSCs triggered by HFS, we prevented D-serine synthesis with the serine racemase inhibitor HOAsp, which has a low molecular weight (148 Da), allowing its passage through gap junction channels and thus its diffusion within the astroglial network (see also $\left[\mathrm{Ca}^{2+}\right]_{\mathrm{i}}$ clamp above). As a first step, we performed dual recordings of a L5PC neuron in the PFC with a pipette containing a standard solution; a nearby astrocyte was patched with a pipette solution containing HOAsp $(400 \mu \mathrm{M})$. This approach resulted in a reduction of $7 \pm 3 \%(n=$ 7) of the NMDA EPSC amplitude. In addition, when the LTP was induced by HFS in L2/3, the potentiation of NMDA EPSCs was reduced (Fig. 8). Indeed, in this set of experiments, NMDA EPSCs were increased after HFS (Fig. $8 A 1, B$ ) by $47 \pm 5 \%$ compared with control ( $p<0.01, t$ test, $n=7)$. When HOAsp was infused within the astroglial network before HFS, the amplitude of NMDA currents measured 30 min after HFS did not show a 
significant LTP (15 $\pm 3 \%$ compared with the LTP control, $p>0.05$ compared with HFS control, $t$ test, $n=7$; Fig. $8 A 2, B)$. Moreover, application of Gap26 did not result in any additive effect on NMDA current amplitude after HOAsp infusion within the astroglial network $(p>0.05$ compared with the control HOAsp alone after HFS, $t$ test, $n=7$ ). Finally, the effect of HOAsp infusion on the HFS induced potentiation of NMDA currents was partially rescued by adding D-serine (100 $\mu \mathrm{M}$ ) in the extracellular solution (Fig. $8 A 3, B)$. Indeed, in the presence of extracellular D-serine, HFS-induced LTP of NMDA EPSCs ( $42 \pm 2 \%)$ was statistically increased compared with that recorded with HOAsp only ( $p<0.01, t$ test, $n=7)$ and close to the values recorded in control condition ( $p>0.05$, $t$ test, $n=7)$. Therefore, as a whole, these data point to a role of astroglial D-serine in the modulation of NMDA-receptors activity that is associated with $\mathrm{Cx} 43$ hemichannel activity.

\section{Discussion}

In PFC pyramidal neurons, the amplitude of NMDA, but not AMPA, synaptic currents triggered by the stimulation of $\mathrm{L} 2 / 3$ is reduced in presence of Gap26, a mimetic peptide that blocks Cx43 hemichannel activity. Because, in the brain, $\mathrm{Cx} 43$ is expressed only in astrocytes during the third week of mouse life, these inhibitory effects reveal an astrocyte-toneuron interaction that affects glutamatergic transmission. Indeed, we show here that $\mathrm{Cx} 43$ hemichannel activity is associated with the release of D-serine by astrocytes that acts as an agonist of the glycine site of neuronal NMDAR and contributes to LTP of NMDA and also AMPA currents after HFS. Our results uncover a neuroglial dia$\log$ where a $\left[\mathrm{Ca}^{2+}\right]_{\mathrm{i}}$-dependent $\mathrm{Cx} 43$ hemichannel function in astrocytes is involved in the modulation of neuronal glutamatergic synaptic activity and plasticity.

The starting point of the present work is the observation that Gap26 reduced the amplitude of NMDA EPSCs, whereas AMPA EPSCs were not affected by this mimetic peptide. This observation indicates that Gap26 does not affect glutamate release in neurons or uptake in astrocytes, but rather affects neuronal NMDARs specifically. Gap26, which targets Cx43 (Wang et al., 2012; see also Fig. 5), is expected to inhibit specifically astrocyte hemichannels without any direct effect on neurons that do not express $\mathrm{Cx} 43$ in 3-week-old mice, the age at which these experiments were performed. Previous studies showed that astrocytes are a source of D-serine in the brain (Schell et al., 1995; Wolosker et al., 1999; but see Wolosker et al., 2016), that D-serine release from astrocytes is $\left[\mathrm{Ca}^{2+}\right]_{\mathrm{i}}$ dependent and at least partially vesicular (Mothet et al., 2005), and that glial D-serine acts on synaptic NMDARs in PFC (Fossat et al., 2012). Based on these data, we hypothesized that $\mathrm{Cx} 43$ hemichannel activity may be involved in the process of $\mathrm{D}$-serine release by astrocytes. This possibility was corroborated by the fact that application of D-serine prevented the reduction of NMDA EPSCs by Gap26. This was also confirmed by the fact that Gap26 had no additive effect on NMDA EPSCs amplitude when a serine racemase inhibitor, HOAsp, was infused within the astroglial network before HFS. Although the specificity of this inhibitor was questioned (Wolosker and Mori, 2012), its reported effect on glutamate reuptake through transporters can be excluded because NMDA currents were reduced, not increased, in the present study. In addition, here, HOAsp was introduced within astrocytes, which limits potential nonspecific effects. Therefore, hemichannel activity contributes to D-serine release by astrocytes. However, this does not necessarily mean that $\mathrm{Cx} 43$ hemichannels provide the direct release pathway for a cytosolic pool of D-serine. Indeed, opened hemichannels allow for $\mathrm{Ca}^{2+}$ influx (Schalper et al., 2010) that can amplify hemichannel activity (see above) and can also trigger $\left[\mathrm{Ca}^{2+}\right]_{\mathrm{i}^{-}}$and SNARE protein-dependent vesicular release of D-serine by astrocytes (Martineau et al., 2013). However, the dissection of these regulatory pathways goes beyond the scope of the present study and this hypothesis remains to be investigated.

Cytoplasmic $\mathrm{Ca}^{2+}$ controls hemichannel activity and previous works have shown that $\mathrm{Cx} 43$ hemichannel activity is characterized by a bell-shaped "convex-up" response to changes in $\left[\mathrm{Ca}^{2+}\right]_{\mathrm{i}}$, with maximal activity in the $500 \mathrm{~nm}$ range and decreasing activities at both higher and lower $\left[\mathrm{Ca}^{2+}\right]_{\mathrm{i}}$. These findings were based on ATP release and dye uptake studies in glioma cell lines and other cell types (De Vuyst et al., 2009; De Bock et al., 2012). Recently, single-channel studies of $\mathrm{Cx} 43$ hemichannels 
A

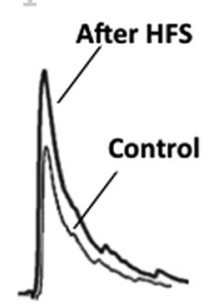

$A_{2}$

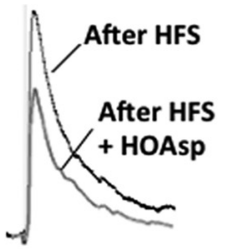

$A_{3}$

B

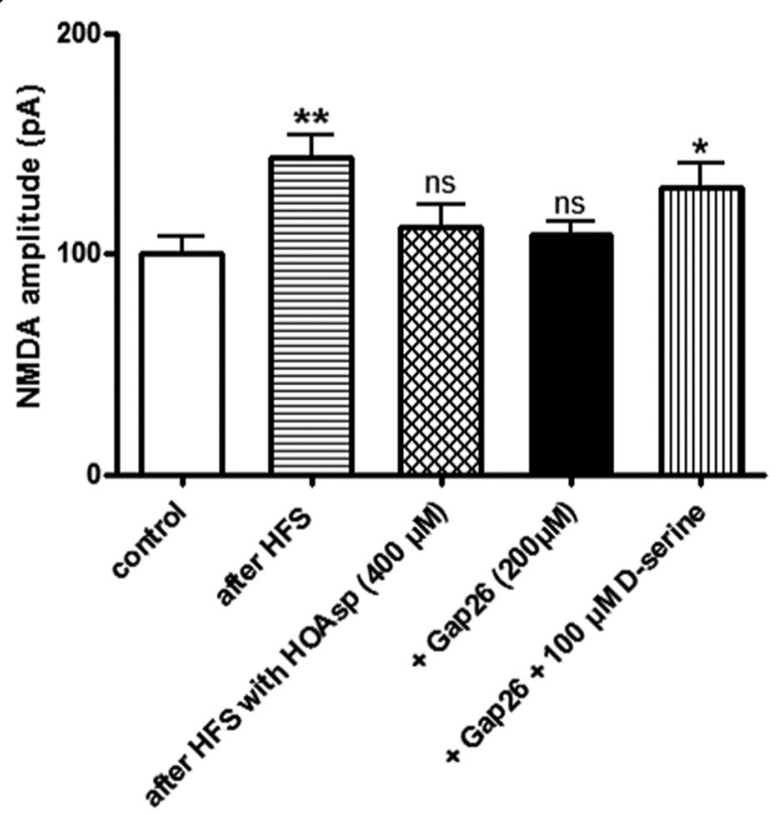

Figure 8. D-serine release by astrocytes requires $C x 43$ hemichannel activation to induce LTP of NMDA EPSCs in PFC pyramidal neurons. A1-A3, Typical average ( $n=5$ consecutive traces) NMDA EPSCs recorded at $+40 \mathrm{mV}$ in the presence of picrotoxin $(100 \mu \mathrm{m})$ and NBQX (10 $\mu \mathrm{M})$. Scale bars, $100 \mathrm{pA}$ and $100 \mathrm{~ms}$. A1, Representative NMDA EPSCs recorded before (Control) and $30 \mathrm{~min}$ after the HFS protocol. A2, NMDA EPSCS recorded $30 \mathrm{~min}$ after the HFS protocol and after infusion of a serine-racemase inhibitor (HOAsp, $400 \mu \mathrm{M}$ ) in the astroglial network. A3, NMDA EPSCs recorded 30 min after the HFS protocol and after infusion of HOAsp in the astroglial network plus D-serine $(100 \mu \mathrm{m})$ in the extracellular solution. C, Summary diagram showing a significant increase of NMDA EPSC amplitude 30 min after the HFS protocol $(p<0.01, t$ test, $n=7$ ) that is prevented after infusion of HOAsp in the astroglial network ( $p>0.05, t$ test, $n=$ 7) and partially rescued by adding D-serine (100 $\mu \mathrm{m})$ in the bath solution (vs HFS $p<0.05$, $t$ test, $n=7)$.

confirmed these observations in HeLa cells transfected with Cx43 (Wang et al., 2012; Bol et al., 2017). Moreover, because Cx hemichannels are permeable to $\mathrm{Ca}^{2+}$ (Sánchez et al., 2009; Schalper et al., 2010; Fiori et al., 2012), their dependency on $\left[\mathrm{Ca}^{2+}\right]_{\mathrm{i}}$ contributes to a $\left[\mathrm{Ca}^{2+}\right]_{\mathrm{i}}$-induced $\mathrm{Ca}^{2+}$ entry pathway. However, so far, the information concerning a possible $\mathrm{Ca}^{2+}$ dependence of $\mathrm{Cx} 43$ hemichannels was lacking for astrocytes. Therefore, we investigated the activity of hemichannels in cultured astrocytes that provide a single-cell system in which only $\mathrm{Cx} 43$, not $\mathrm{Cx} 30$, the other astroglial Cx, is expressed (Giaume et al., 1991; Koulakoff et al., 2008) and where astrocytes are not coupled together as they are used at subconfluence. First, using EtBr uptake assays, we were able to show that $\left[\mathrm{Ca}^{2+}\right]_{\mathrm{i}}$ increases generated by application of ionomycin activate hemichannels, a process that was abolished by either CBX or Gap26. Second, single-channel patch-clamp recordings confirmed these observations and demonstrated that an elevation of $\left[\mathrm{Ca}^{2+}\right]_{\mathrm{i}}$ to $200 \mathrm{~nm}$ activated $\mathrm{Cx} 43$ hemichannels and that Gap26 inhibited them. Interestingly, their activity was also recorded at very negative potentials similar to the resting potential of astrocytes, as reported previously for cortical astrocytes treated either with proinflammatory cytokines or the $\beta$-amyloid peptide (Retamal et al., 2007; Orellana et al., 2011). Based on these observations, our experiments of $\mathrm{Ca}^{2+}$ clamp performed in acute PFC slices can be interpreted as a situation in which $\left[\mathrm{Ca}^{2+}\right]_{\mathrm{i}}$ is maintained at a low level, likely $\sim 50-80 \mathrm{nM}$, as indicated by Henneberger et al. (2010), and hemichannel activity is limited.

The present study suggests an important role of astroglial D-serine in modulating NMDA receptor activity and thus synaptic plasticity in the PFC in a $\left[\mathrm{Ca}^{2+}\right]_{\mathrm{i}}$-dependent manner. This modulation also affected the LTP of AMPA EPSCs that was reduced in the presence of Gap26. This statement is in agreement with the previous work of Henneberger et al. (2010), who reported a $\left[\mathrm{Ca}^{2+}\right]_{\mathrm{i}}$-dependent release of $\mathrm{D}$-serine from astrocytes controlling synaptic plasticity in the hippocampus. Importantly, our study also provides novel evidence implying $\mathrm{Cx} 43$ hemichannels in the D-serine neuroglial dialogue regulating neurotransmission. For LTP induction, we used a classical theta-burst stimulation protocol and clamped $\left[\mathrm{Ca}^{2+}\right]_{\mathrm{i}}$ close to its basal level. These conditions differ from a recent work in CA1 hippocampal neurons showing that induction of spike-timing-dependent LTP was not affected in presence of BAPTA in astrocytes or slices incubated with the astrogliotoxin fluoroacetate (AndradeTalavera et al., 2016). Such discrepancies in the contribution of astrocytes in neuronal plasticity emphasize the importance of the differences in protocols used to induce synaptic plasticity, the brain region investigated, and the way to control $\left[\mathrm{Ca}^{2+}\right]_{\mathrm{i}}$ changes (BAPTA vs EGTA+low $\mathrm{Ca}^{2+}$ ) in astrocytes, which of course involve different cellular and molecular events that can result or not in the abovementioned neuroglial partnership.

There is increasing evidence that astrocyte Cxs contribute to neuroglial interactions (Giaume et al., 2010; Pannasch and Rouach, 2013). In the double $\mathrm{Cx} 43 / \mathrm{Cx} 30 \mathrm{KO}$ mouse, in which the two major astroglial Cxs are lacking, hippocampal synaptic transmission and plasticity are affected due to modification in extracellular homeostasis (Pannasch et al., 2011). Moreover, $\mathrm{Cx}$-mediated intercellular communication provides an astroglial metabolic pathway that allows the trafficking of energy substrates from the glio-vascular interface to the synapses and contributes to synaptic activity (Giaume et al., 2010). Conversely, whereas astrocyte hemichannels were initially thought to operate exclusively in inflammatory situations or in pathological contexts (Bennett et al., 2012), their contribution was demonstrated in tanycytes treated with glucose and in HeLa cells transfected with various Cxs treated with FGF-1 (Schalper et al., 2008). In addition, when studied in basal conditions either in the hippocampus (Chever et al., 2014) or in the olfactory bulb (Roux et al., 2015), astroglial $\mathrm{Cx} 43$ hemichannel activity affects the excitatory synaptic transmission and slow oscillations, respectively. Interestingly, in both cases, ATP/adenosine signaling linked to $\mathrm{Cx} 43 \mathrm{hemi-}$ channel activity in astrocytes was responsible for the changes in these neuronal properties. Moreover, in vivo evidence indicates that gliotransmission linked to $\mathrm{Cx} 43$ hemichannels is necessary for fear memory consolidation at the rat basolateral amygdala with a possible contribution of D-serine (Stehberg et al., 2012). In the present study, we provide for the first time evidence that astrocyte $\mathrm{Cx} 43$ hemichannels are involved in the acute and longterm modulation of glutamatergic EPSCs through D-serine release by astrocytes of the PFC. Therefore, the contribution of $\mathrm{Cx} 43$ hemichannels to gliotransmission would not only be medi- 
ated by ATP (Kang et al., 2008) and glutamate (Ye et al., 2003; Abudara et al., 2015), but also by D-serine, showing their key role in the modulation of synaptic function. This may be particularly relevant in brain structures where $\mathrm{D}$-serine and serine racemase are known to be present at a relatively high concentration, such as in the PFC (Hashimoto et al., 1995; Fossat et al., 2012).

\section{References}

Abudara V, Roux L, Dallérac G, Matias I, Dulong J, Mothet JP, Rouach N, Giaume C (2015) Activated microglia impairs neuroglial interaction by opening Cx43 hemichannels in hippocampal astrocytes. Glia 63:795-811. CrossRef Medline

Agulhon C, Fiacco TA, McCarthy KD (2010) Hippocampal short- and longterm plasticity are not modulated by astrocyte $\mathrm{Ca} 2+$ signaling. Science 327:1250-1254. CrossRef Medline

Andersson M, Blomstrand F, Hanse E (2007) Astrocytes play a critical role in transient heterosynaptic depression in the rat hippocampal CA1 region. J Physiol 585:843-852. CrossRef Medline

Andrade-Talavera Y, Duque-Feria P, Paulsen O, Rodríguez-Moreno A (2016) Presynaptic spike timing-dependent long-term depression in the mouse hippocampus. Cereb Cortex 26:3637-3654. CrossRef Medline

Bazargani N, Attwell D (2016) Astrocyte calcium signaling: the third wave. Nat Neurosci 19:182-189. CrossRef Medline

Bennett MV, Garré JM, Orellana JA, Bukauskas FF, Nedergaard M, Sáez JC (2012) Connexin and pannexin hemichannels in inflammatory responses of glia and neurons. Brain Res 1487:3-15. CrossRef Medline

Bernardinelli Y, Randall J, Janett E, Nikonenko I, König S, Jones EV, Flores CE, Murai KK, Bochet CG, Holtmaat A, Muller D (2014) Activitydependent structural plasticity of perisynaptic astrocytic domains promotes excitatory synapse stability. Curr Biol 24:1679-1688. CrossRef Medline

Bezzi P, Gundersen V, Galbete JL, Seifert G, Steinhäuser C, Pilati E, Volterra A (2004) Astrocytes contain a vesicular compartment that is competent for regulated exocytosis of glutamate. Nat Neurosci 7:613-620. CrossRef Medline

Blomstrand F, Giaume C, Hansson E, Rönnbäck L (1999) Distinct pharmacological properties of ET-1 and ET-3 on astroglial gap junctions and $\mathrm{Ca}(2+)$ signaling. Am J Physiol 277:C616-C627. Medline

Bol M, Wang N, De Bock M, Wacquier B, Decrock E, Gadicherla A, Decaluwé K, Vanheel B, van Rijen HV, Krysko DV, Bultynck G, Dupont G, Van de Voorde J, Leybaert L (2017) At the cross-point of connexins, calcium and ATP: blocking hemichannels inhibits vasoconstriction of rat small mesenteric arteries. Cardiovasc Res 113:195-206. CrossRef Medline

Chaytor AT, Evans WH, Griffith TM (1997) Peptides homologous to extracellular loop motifs of connexin 43 reversibly abolish rhythmic contractile activity in rabbit arteries. J Physiol 503:99-110. CrossRef Medline

Chever O, Lee CY, Rouach N (2014) Astroglial connexin 43 hemichannels tune basal excitatory synaptic transmission. J Neurosci 34:11228-11232. CrossRef Medline

De Bock M, Wang N, Bol M, Decrock E, Ponsaerts R, Bultynck G, Dupont G, Leybaert L (2012) Connexin 43 hemichannels contribute to cytoplasmic $\mathrm{Ca} 2+$ oscillations by providing a bimodal $\mathrm{Ca} 2+$-dependent $\mathrm{Ca} 2+$ entry pathway. J Biol Chem 287:12250-12266. CrossRef Medline

Decrock E, De Vuyst E, Vinken M, Van Moorhem M, Vranckx K, Wang N, Van Laeken L, De Bock M, D'Herde K, Lai CP, Rogiers V, Evans WH, Naus CC, Leybaert L (2009) Connexin 43 hemichannels contribute to the propagation of apoptotic cell death in a rat C6 glioma cell model. Cell Death Differ 16:151-163. CrossRef Medline

De Nardo LA, Berns DS, DeLoach K, Luo L (2015) Connectivity of mouse somatosensory and prefrontal cortex examined with trans-synaptic tracing. Nat Neurosci 18:1687-1697. CrossRef Medline

Desplantez T, Verma V, Leybaert L, Evans WH, Weingart R (2012) Gap26, a connexin mimetic peptide, inhibits currents carried by connexin 43 hemichannels and gap junction channels. Pharmacol Res 65:546-552. CrossRef Medline

De Vuyst E, Wang N, Decrock E, De Bock M, Vinken M, Van Moorhem M, Lai C, Culot M, Rogiers V, Cecchelli R, Naus CC, Evans WH, Leybaert L (2009) $\mathrm{Ca}(2+)$ regulation of connexin 43 hemichannels in C6 glioma and glial cells. Cell Calcium 46:176-187. CrossRef Medline

Ding X, Ma N, Nagahama M, Yamada K, Semba R (2011) Localization of $\mathrm{D}$-serine and serine racemase in neurons and neuroglias in mouse brain. Neurol Sci 32:263-267. CrossRef Medline
Ehmsen JT, Ma TM, Sason H, Rosenberg D, Ogo T, Furuya S, Snyder SH, Wolosker H (2013) D-serine in glia and neurons derives from 3-phosphoglycerate dehydrogenase. J Neurosci 33:12464-12469. CrossRef Medline Fiacco TA, Agulhon C, Taves SR, Petravicz J, Casper KB, Dong X, Chen J, McCarthy KD (2007) Selective stimulation of astrocyte calcium in situ does not affect neuronal excitatory synaptic activity. Neuron 54:611-626. CrossRef Medline

Fiori MC, Figueroa V, Zoghbi ME, Saéz JC, Reuss L, Altenberg GA (2012) Permeation of calcium through purified connexin 26 hemichannels. J Biol Chem 287:40826-40834. CrossRef Medline

Fossat P, Turpin FR, Sacchi S, Dulong J, Shi T, Rivet JM, Sweedler JV, Pollegioni L, Millan MJ, Oliet SH, Mothet JP (2012) Glial D-serine gates NMDA receptors at excitatory synapses in prefrontal cortex. Cereb Cortex 22:595-606. CrossRef Medline

Genoud C, Houades V, Kraftsik R, Welker E, Giaume C (2015) Proximity of excitatory synapses and astroglial gap junctions in layer IV of the mouse barrel cortex. Neuroscience 291:241-249. CrossRef Medline

Giaume C, Fromaget C, el Aoumari A, Cordier J, Glowinski J, Gros D (1991) Gap junctions in cultured astrocytes: single-channel currents and characterization of channel-forming protein. Neuron 6:133-143. CrossRef Medline

Giaume C, Koulakoff A, Roux L, Holcman D, Rouach N (2010) Astroglial networks: a step further in neuroglial and gliovascular interactions. Nat Rev Neurosci 11:87-99. CrossRef Medline

Giaume C, Orellana JA, Abudara V, Sáez JC (2012) Connexin-based channels in astrocytes: how to study their properties. Methods Mol Biol 814: 283-303. CrossRef Medline

Giaume C, Leybaert L, Naus CC, Sáez JC (2013) Connexin and pannexin hemichannels in brain glial cells: properties, pharmacology, and roles. Front Pharmacol 4:88. CrossRef Medline

Gundersen V, Storm-Mathisen J, Bergersen LH (2015) Neuroglial transmission. Physiol Rev 95:695-726. CrossRef Medline

Harney SC, Rowan M, Anwyl R (2006) Long-term depression of NMDA receptor-mediated synaptic transmission is dependent on activation of metabotropic glutamate receptors and is altered to long-term potentiation by low intracellular calcium buffering. J Neurosci 26:1128-1132. CrossRef Medline

Hashimoto A, Oka T, Nishikawa T (1995) Extracellular concentration of endogenous free $\mathrm{D}$-serine in the rat brain as revealed by in vivo microdialysis. Neuroscience 66:635-643. CrossRef Medline

Henneberger C, Papouin T, Oliet SH, Rusakov DA (2010) Long-term potentiation depends on release of D-serine from astrocytes. Nature 463: 232-236. CrossRef Medline

Kang J, Kang N, Lovatt D, Torres A, Zhao Z, Lin J, Nedergaard M (2008) Connexin 43 hemichannels are permeable to ATP. J Neurosci 28:47024711. CrossRef Medline

Kang N, Peng H, Yu Y, Stanton PK, Guilarte TR, Kang J (2013) Astrocytes release D-serine by a large vesicle. Neuroscience 240:243-257. CrossRef Medline

Kettenmann H and Zorec R (2013) Release of gliotransmitters and transmitter receptors in astrocytes. In: Neuroglia, Ed 3. (Kettenmann H, Ransom BR, eds), pp 292-305. Oxford: OUP.

Khakh BS, McCarthy KD (2015) Astrocyte calcium signaling: from observations to functions and the challenges therein. Cold Spring Harb Perspect Biol 7:a020404. CrossRef Medline

Koulakoff A, Ezan P, Giaume C (2008) Neurons control the expression of connexin 30 and connexin 43 in mouse cortical astrocytes. Glia 56:1299_ 1311. CrossRef Medline

Lewis DA, Glantz LA, Pierri JN, Sweet RA (2003) Altered cortical glutamate neurotransmission in schizophrenia: evidence from morphological studies of pyramidal neurons. Ann N Y Acad Sci 1003:102-112. CrossRef Medline

Liu X, Petit JM, Ezan P, Gyger J, Magistretti P, Giaume C (2013) The psychostimulant modafinil enhances gap junctional communication in cortical astrocytes. Neuropharmacology. 75:533-538. CrossRef Medline

Martineau M, Baux G, Mothet JP (2006) Gliotransmission at central glutamatergic synapses: D-serine on stage. J Physiol (Paris) 99:103-110. CrossRef Medline

Martineau M, Galli T, Baux G, Mothet JP (2008) Confocal imaging and tracking of the exocytotic routes for D-serine-mediated gliotransmission. Glia 56:1271-1284. CrossRef Medline

Martineau M, Shi T, Puyal J, Knolhoff AM, Dulong J, Gasnier B, Klingauf J, 
Sweedler JV, Jahn R, Mothet JP (2013) Storage and uptake of D-serine into astrocytic synaptic-like vesicles specify gliotransmission. J Neurosci 33:3413-3423. CrossRef Medline

Martineau M, Parpura V, Mothet JP (2014) Cell-type specific mechanisms of D-serine uptake and release in the brain. Front Synaptic Neurosci 6:12. CrossRef Medline

Même W, Calvo CF, Froger N, Ezan P, Amigou E, Koulakoff A, Giaume C (2006) Proinflammatory cytokines released from microglia inhibit gap junctions in astrocytes: potentiation by beta-amyloid. FASEB J 20:494496. Medline

Miya K, Inoue R, Takata Y, Abe M, Natsume R, Sakimura K, Hongou K, Miyawaki T, Mori H (2008) Serine racemase is predominantly localized in neurons in mouse brain. J Comp Neurol 510:641-654. CrossRef Medline

Morris RG (2013) NMDA receptors and memory encoding. Neuropharmacology 74:32-40. CrossRef Medline

Mothet JP, Parent AT, Wolosker H, Brady RO Jr, Linden DJ, Ferris CD, Rogawski MA, Snyder SH (2000) D-serine is an endogenous ligand for the glycine site of the N-methyl-D-aspartate receptor. Proc Natl Acad Sci U S A 97:4926-4931. CrossRef Medline

Mothet JP, Pollegioni L, Ouanounou G, Martineau M, Fossier P, Baux G (2005) Glutamate receptor activation triggers a calcium-dependent and SNARE protein-dependent release of the gliotransmitter D-serine. Proc Natl Acad Sci U S A 102:5606-5611. CrossRef Medline

Nagy JI, Rash JE (2000) Connexins and gap junctions of astrocytes and oligodendrocytes in the CNS. Brain Res Brain Res Rev 32:29-44. CrossRef Medline

Nicoll RA, Schmitz D (2005) Synaptic plasticity at hippocampal mossy fibre synapses. Nat Rev Neurosci 6:863-876. Medline

Nolte C, Matyash M, Pivneva T, Schipke CG, Ohlemeyer C, Hanisch UK, Kirchhoff F, Kettenmann H (2001) GFAP promoter-controlled EGFPexpressing transgenic mice: a tool to visualize astrocytes and astrogliosis in living brain tissue. Glia 33:72-86. Medline

Orellana JA, Froger N, Ezan P, Jiang JX, Bennett MV, Naus CC, Giaume C, Sáez JC (2011) ATP and glutamate released via astroglial connexin 43 hemichannels mediate neuronal death through activation of pannexin 1 hemichannels. J Neurochem 118:826-840. CrossRef Medline

Panatier A, Theodosis DT, Mothet JP, Touquet B, Pollegioni L, Poulain DA, Oliet SH (2006) Glia-derived D-serine controls NMDA receptor activity and synaptic memory. Cell 125:775-784. CrossRef Medline

Pannasch U, Rouach N (2013) Emerging role for astroglial networks in information processing: from synapse to behavior. Trends Neurosci 36: 405-417. CrossRef Medline

Pannasch U, Vargová L, Reingruber J, Ezan P, Holcman D, Giaume C, Syková E, Rouach N (2011) Astroglial networks scale synaptic activity and plasticity. Proc Natl Acad Sci U S A 108:8467-8472. CrossRef Medline

Papouin T, Ladépêche L, Ruel J, Sacchi S, Labasque M, Hanini M, Groc L, Pollegioni L, Mothet JP, Oliet SH (2012) Synaptic and extrasynaptic NMDA receptors are gated by different endogenous coagonists. Cell 150: 633-646. CrossRef Medline

Poels EM, Kegeles LS, Kantrowitz JT, Javitt DC, Lieberman JA, Abi-Dargham A, Girgis RR (2014) Glutamatergic abnormalities in schizophrenia: A review of proton MRS findings. Schizophr Res 152:325-332. CrossRef Medline

Retamal MA, Froger N, Palacios-Prado N, Ezan P, Sáez PJ, Sáez JC, Giaume C (2007) Cx43 hemichannels and gap junction channels in astrocytes are regulated oppositely by proinflammatory cytokines released from activated microglia. J Neurosci 27:13781-13792. CrossRef Medline

Roux L, Madar A, Lacroix MM, Yi C, Benchenane K, Giaume C (2015) Astroglial connexin 43 hemichannels modulate olfactory bulb slow oscillations. J Neurosci 35:15339-15352. CrossRef Medline
Sánchez HA, Orellana JA, Verselis VK, Sáez JC (2009) Metabolic inhibition increases activity of connexin-32 hemichannels permeable to $\mathrm{Ca} 2+$ in transfected HeLa cells. Am J Physiol Cell Physiol 297:C665-C678. CrossRef Medline

Scemes E, Giaume C (2006) Astrocyte calcium waves: what they are and what they do. Glia 54:716-725. CrossRef Medline

Schalper KA, Palacios-Prado N, Retamal MA, Shoji KF, Martínez AD, Sáez JC (2008) Connexin hemichannel composition determines the FGF-1induced membrane permeability and free $[\mathrm{Ca} 2+]$ i responses. Mol Biol Cell 19:3501-3513. CrossRef Medline

Schalper KA, Sánchez HA, Lee SC, Altenberg GA, Nathanson MH, Sáez JC (2010) Connexin 43 hemichannels mediate the Ca2 + influx induced by extracellular alkalinization. Am J Physiol Cell Physiol 299:C1504-C1515. CrossRef Medline

Schell MJ, Molliver ME, Snyder SH (1995) D-serine, an endogenous synaptic modulator: localization to astrocytes and glutamate-stimulated release. Proc Natl Acad Sci U S A 92:3948-3952. CrossRef Medline

Stehberg J, Moraga-Amaro R, Salazar C, Becerra A, Echeverría C, Orellana JA, Bultynck G, Ponsaerts R, Leybaert L, Simon F, Sáez JC, Retamal MA (2012) Release of gliotransmitters through astroglial connexin 43 hemichannels is necessary for fear memory consolidation in the basolateral amygdala. FASEB J 26:3649-3657. CrossRef Medline

Strisovsky K, Jiraskova J, Mikulova A, Rulisek L, Konvalinka J (2005) Dual substrate and reaction specificity in mouse serine racemase: identification of high-affinity dicarboxylate substrate and inhibitors and analysis of the $\beta$-eliminase activity. Biochemistry 44:13091-13100. CrossRef Medline

Tan HY, Callicott JH, Weinberger DR (2007) Dysfunctional and compensatory prefrontal cortical systems, genes and the pathogenesis of schizophrenia. Cereb Cortex 17:i171-i181. CrossRef Medline

Theis M, Jauch R, Zhuo L, Speidel D, Wallraff A, Döring B, Frisch C, Söhl G, Teubner B, Euwens C, Huston J, Steinhäuser C, Messing A, Heinemann U, Willecke K (2003) Accelerated hippocampal spreading depression and enhanced locomotory activity in mice with astrocyte-directed inactivation of connexin43. J Neurosci 23:766-776. Medline

Venance L, Prémont J, Glowinski J, Giaume C (1998) Gap junctional communication and pharmacological heterogeneity in astrocytes cultured from the rat striatum. J Physiol 510:429-440. CrossRef Medline

Wang N, De Bock M, Antoons G, Gadicherla AK, Bol M, Decrock E, Evans WH, Sipido KR, Bukauskas FF, Leybaert L (2012) Connexin mimetic peptides inhibit $\mathrm{Cx} 43$ hemichannel opening triggered by voltage and intracellular Ca2+ elevation. Basic Res Cardiol 107:304. CrossRef Medline

Wolosker H (2007) NMDA receptor regulation by D-serine: new findings and perspectives. Mol Neurobiol 36:152-164. CrossRef Medline

Wolosker H, Mori H (2012) Serine racemase: an unconventional enzyme for an unconventional transmitter. Amino Acids 43:1895-1904. CrossRef Medline

Wolosker H, Blackshaw S, Snyder SH (1999) Serine racemase: a glial enzyme synthesizing D-serine to regulate glutamate-N-methyl-D-aspartate neurotransmission. Proc Natl Acad Sci U S A 96:13409-13414. CrossRef Medline

Wolosker H, Balu DT, Coyle JT (2016) The rise and fall of the D-serinemediated gliotransmission hypothesis. Trends Neurosci 39:712-721. CrossRef Medline

Ye ZC, Wyeth MS, Baltan-Tekkok S, Ransom BR (2003) Functional hemichannels in astrocytes: a novel mechanism of glutamate release. J Neurosci 23:3588-3596. Medline

Zhao MG, Toyoda H, Lee YS, Wu LJ, Ko SW, Zhang XH, Jia Y, Shum F, Xu H, Li BM, Kaang BK, Zhuo M (2005) Roles of NMDA NR2B subtype receptor in prefrontal long-term potentiation and contextual fear memory. Neuron 47:859-872. CrossRef 